\title{
When Does Education Matter? The Protective Effect of Education for Cohorts Graduating in Bad Times
}

\section{Citation}

Cutler, David M., Wei Huang, and Adriana Lleras-Muney. Forthcoming. "When Does Education Matter? The Protective Effect of Education for Cohorts Graduating in Bad Times." Social Science and Medicine.

\section{Published Version}

doi:10.1016/j.socscimed.2014.07.056

\section{Permanent link}

http://nrs.harvard.edu/urn-3:HUL.InstRepos:13479095

\section{Terms of Use}

This article was downloaded from Harvard University's DASH repository, and is made available under the terms and conditions applicable to Open Access Policy Articles, as set forth at http:// nrs.harvard.edu/urn-3:HUL.InstRepos:dash.current.terms-of-use\#OAP

\section{Share Your Story}

The Harvard community has made this article openly available.

Please share how this access benefits you. Submit a story.

\section{Accessibility}




\title{
WHEN DOES EDUCATION MATTER? THE PROTECTIVE EFFECT OF EDUCATION FOR COHORTS GRADUATING IN BAD TIMES
}

\author{
David Cutler \\ Wei Huang \\ Adriana Lleras-Muney \\ Working Paper 20156 \\ http://www.nber.org/papers/w20156 \\ NATIONAL BUREAU OF ECONOMIC RESEARCH \\ 1050 Massachusetts Avenue \\ Cambridge, MA 02138 \\ May 2014
}

Wei Huang would like to thank the funding support from NBER Pre-doc fellowship in Aging and Health Economics. This research was supported by the National Institute on Aging. The views expressed herein do not necessarily reflect the views of the National Bureau of Economic Research.

At least one co-author has disclosed a financial relationship of potential relevance for this research. Further information is available online at http://www.nber.org/papers/w20156.ack

NBER working papers are circulated for discussion and comment purposes. They have not been peerreviewed or been subject to the review by the NBER Board of Directors that accompanies official NBER publications.

(C) 2014 by David Cutler, Wei Huang, and Adriana Lleras-Muney. All rights reserved. Short sections of text, not to exceed two paragraphs, may be quoted without explicit permission provided that full credit, including $(\mathcal{C}$ notice, is given to the source. 
When Does Education Matter? The Protective Effect of Education for Cohorts Graduating

in Bad Times

David Cutler, Wei Huang, and Adriana Lleras-Muney

NBER Working Paper No. 20156

May 2014

JEL No. I12,I20,J11

\begin{abstract}
Using Eurobarometer data, we document large variation across European countries in education gradients in income, self-reported health, life satisfaction, obesity, smoking and drinking. While this variation has been documented previously, the reasons why the effect of education on income, health and health behaviors varies is not well understood. We build on previous literature documenting that cohorts graduating in bad times have lower wages and poorer health for many years after graduation, compared to those graduating in good times. We investigate whether more educated individuals suffer smaller income and health losses as a result of poor labor market conditions upon labor market entry. We confirm that a higher unemployment rate at graduation is associated with lower income, lower life satisfaction, greater obesity, more smoking and drinking later in life. Further, education plays a protective role for these outcomes, especially when unemployment rates are high: the losses associated with poor labor market outcomes are substantially lower for more educated individuals. Variation in unemployment rates upon graduation can potentially explain a large fraction of the variance in gradients across different countries.
\end{abstract}

David Cutler

Department of Economics

Harvard University

1875 Cambridge Street

Cambridge, MA 02138

and NBER

dcutler@harvard.edu

Wei Huang

Harvard University and NBER

1050 Massachusetts Avenue

Cambridge, MA 02138

huangw@nber.org

\author{
Adriana Lleras-Muney \\ Department of Economics \\ 9373 Bunche Hall \\ UCLA \\ Los Angeles, CA 90095 \\ and NBER \\ alleras@ECON.UCLA.EDU
}




\section{Introduction}

A long line of literature has examined the impact of education on health and health behaviors (Cutler and Lleras-M uney 2010a, 2010b). A Imost all observational studies find that education is positively associated with health, but two points are worth noting. First, there is substantial variation across countries and cohorts in the extent to which education predicts better heal th. For example K unst and M ackenbach (1994) document that education has a small effect on mortality in the Netherlands, Sweden, Denmark, and Norway but its effect is about two times as large in the United States, France, or Italy. And this association is larger for more recent cohorts: education is a larger predictor of mortality today than in the past (M eara, Richards and Cutler 2008). Education gradients in health behaviors also vary substantially: for instance Cutler and Lleras-M uney (2013) document that the effect of a year of education on smoking for women ranges from 0.02 to -0.06 depending on the country. Second not all studies find that education is protective. Most notably, recent attempts to estimate causal impacts of education using compulsory schooling legislation find different results across countries. For instance, compulsory schooling reduced mortality in the U nited States (Lleras-M uney 2005) but not in England (Clark and Royer 2013), or France (Albouy and Lequien 2009), and the effects for Sweden are ambiguous (M eghir et al. 2013, Fischer et al. 2013). A recent study that looked at the impact of compulsory school on mortality for several European countries confirms this variability, finding large effects of the reforms on mortality for example in Belgium but not in Spain (Gathmann, Jurges and Reinhold 2012).

In this paper, we explore one explanation for this variability: that the effect of education is larger for cohorts who started their career in bad economic times. Previous literature has documented that individuals graduating in recessions have worse labor market outcomes and health outcomes for many years thereafter (Oreopoulos, Heinz and von W atcher 2012, Genda et al. 2010, Kahn 2010, Kondo 2007, K won et al. 2010, Oyer 2006, 2008, Schoar and Zuo 2011, $M$ acLean 2013). Because education is thought to affect health in part through its effect on income and resources, we hypothesize that the health benefits of education will be lower for individuals for whom education has a smaller return in the labor market. If lifetime incomes increase the demand for health (Grossman 1972), and recessions increase the gap in lifetime incomes across education groups, then recessions will also increase health gaps across education groups. Whether recessions have larger or smaller effects on the lifetime incomes of low 
educated is not clear: in Canada, Oreopoulos, Heinz, and von W atcher (2012) find larger effects of recessions on incomes for those with lower quality of education (college and mayor) but they only study college graduates. Genda et al. (2010) find larger effects on employment for the uneducated in both J apan and the US, but larger effects on income for highly educated in the US.

Education has been hypothesized to increase one's ability to cope with negative shocks and uncertainty. This provides a different reason why economic downturns may have deleterious health effects that differ across education groups. During recessions individuals are more likely to suffer from depression and stress (Cooper 2011) and suicides are higher (Stuckler et al. 2011, Reeves et al. 2012). Unhealthy behaviors also appear to respond to recessions in the short run: both smoking and excessive alcohol consumption fall with unemployment (e.g. Ettner 1997, Rhum 1995, 2003, Rhum and Black 2002, Gerdtham and Rhum 2006 for the US; M ontgomery et al. 1998 for the United K ingdom), as does B M I (Ruhm 2004 but see Jónsdóttir and Á sgeirsdóttir, 2013). Education is associated with overall better mental health and higher rates of healthpromoting behaviors (Cutler and Lleras-M uney 2010b): we hypothesize this association is larger for those graduating in bad times.

We investigate this theory by examining how education affects the income and health returns to early life labor market conditions. Our analysis is based on Eurobarometer data for 31 countries over the past 50 years. We document that the deleterious effect of recessions is substantially smaller for those with high education. In other words, individuals who graduated in a bad economy are more likely to smoke and drink later in life, but this is less true among the better educated. We observe that education is protective for all of the outcomes we study, although the estimates are not always statistically significant. Our results suggest that a sizeable portion of the cross-country variation in the education gradient can be attributed to differences in unemployment rates.

The variability in the return to schooling in the labor market is also large. Psacharopolous and Patrinos (2004) document that the wage returns to education vary significantly across countries, ranging from $3 \%$ to more than $20 \%$ per year of school. Similar to the findings for health, studies investigating the effects of compulsory schooling on wages document a large range of estimates ( $C$ ard 2001). Economics has emphasized the same theoretical and econometric explanation for these findings: they strongly suggest that the returns to schooling are heterogeneous. However the specific sources of heterogeneity are not well-understood. Our 
findings suggest that the labor market conditions under which individuals graduate can explain a substantial amount of the observed heterogeneity in returns to education in the labor market and also contribute to lifetime gaps in income and wellbeing by education. Although we cannot estimate causal effects of education - we only document associations, these results suggest that the returns to education vary depending on economic conditions over the lifetime.

Our paper is also part of a larger literature documenting the unequal impacts of recessions across demographic groups (Engemann and W all 2010, Cynthia et al. 2012, Borges-M endez, Denhardt and M ichelle, 2013). The Great Recession's impact on youth in the United States and Europe has been particularly large, with unemployment rates among individuals aged 16-25 reaching a peak of about $20 \%$ in the US and rising even higher in Europe. Not only are these rates historically high, they are much higher than the unemployment rates among older adults (Bell and Blachflower 2011). Our findings suggest that the impact of the Great Recession on current cohorts is likely to be large and will generate relatively large disparities by education in both health and income as these cohorts age.

\section{Methods}

\section{a. Data}

We use the Standard and Special Topic Eurobarometer Series, the longest running regular cross-national and cross-temporal opinion poll program in Europe. Starting in 1997 and up to 2012, 31 countries in Europe conducted face-to-face interviews in spring and autumn (http://zacat.gesis.org/webview/). We restrict all analyses to individuals aged between 25 and 55 to minimize measurement error in education due to recall, and to minimize the effect of selective mortality by education, most of which will occur after age 55 . Our outcomes of interest are not collected consistently every year - for each outcome we include all possible observations to maximize sample size. Details of the years covered for each outcome are in Table 1.

[Table 1 about here]

Measures of Income and Health

We investigate six outcomes. The first is income. The respondents are asked countryspecific questions about their household income and the answers are categorized into eleven categories in different currency unit. The Eurobarometer principal investigators recode these into 
four income quartiles so that comparisons can be made consistently across the European countries. The variable we use ranges between 1 (top quartile) and 4 (bottom quartile).

Our second and third measures capture overall well-being. Life dissatisfaction is equal to one if the respondent feels unsatisfied or very unsatisfied with his/her life and zero if they report being satisfied or very satisfied. Self-rated satisfaction scores have been shown to be valid and reliable proxies for utility (Lepper 1998, Sandvik et al. 1993). Our measure of self-reported health is based on the question "How is your health in general?," for which the answers are 1 for very good, 2 for good, 3 for not bad and not good, 4 for bad and 5 for very bad. We construct an indicator for poor health, equal to one if the answer is 4 or 5 , and zero otherwise. This subjective measure of health has been shown to be highly predictive of mortality and other objective measures of health (Idler and B enjamini 1997, M artinez et al. 2010, Latham and Peek 2013).

Finally, we have three measures of health behaviors. We use self-reported height and weight to calculate BMI. We define obesity equal to one for those with a BMI greater than 30 (excluding outliers with BMI above 60 , about 0.1 percent of the sample). Although self-reported measures of height and weight suffer from well-known biases, there is no evidence that theis bias is systematically correlated with education (B urkhauser and Cawley 2008).

We construct an indicator of current smoking and an indicator for whether the individual drinks every day. The latter is an imperfect measure of excessive alcohol consumption, but it is the only measure of alcohol consumption available. The relationship between alcohol and mortality is depicted as a J-shaped curve, attributed to a combination of beneficial and harmful effects (White et al. 2002, G mel et al. 2003, Bagnardi et al. 2004). Since daily but moderate drinking is associated with lower mortality (Castelnuovo et al. 2006) and higher incomes (Cook and $\mathrm{M}$ oore 2002), changes in this measure are more difficult to interpret as detrimental.

\section{Education}

The Eurobarometer does not ask years of schooling directly. Instead, the survey asks individuals their age at graduation from their highest degree. We compute years of schooling as the age at graduation minus seven. We drop those whose years of education is over 25 (1.5 percent of the sample) because people who finished schooling at later ages likely took some break in their education. 
The benefit of this imputation is that we can measure years of schooling across all countries consistently. But this measure ignores the variation in age when people starting going to school. M ore importantly if individuals delay graduation in bad times, this behavior will bias

our results. To assess the quality of our measure, we compare our measure of years of school to reports of years of education from the Survey of Health, Ageing and Retirement in Europe (SHARE). Figure A la reports the mean years of schooling against graduation cohorts, for both SHARE and the Eurobarometer, and shows that average education trends are almost identical in both data sets, al though the Eurobarometer slightly overestimates average education for the older cohorts, and underestimates it for the very youngest. Figure A $1 \mathrm{~b}$ plots average years of education by gender, country and graduation year in the SHARE data against average imputed years in the Eurobarometer. The points are distributed almost symmetrically along the 45-degree line, suggesting no systematic bias in our education measure. The correlation between the two measures is 0.90 . We nevertheless conduct several robustness checks to assess how measurement error in education biases our results. Lastly note that the variation of education in these data is large: 27 percent of the population has fewer than 9 years of education, while 37 percent have more than 12 years of education.

\section{U nemployment Rates}

The earliest year at which a person finished their education in our sample was 1948 (a person aged 55 in 1997 who finished their education at age 7 - that is they had no schooling). Thus, we need to measure country-specific unemployment from 1948 on. There is no single source of unemployment data covering that period for all countries. We combine data from four sources. The more recent unemployment rate data are from World Development Indicators (WDI) published by the World Bank. These data are supplemented by historical unemployment rates from the $O E C D$. The unemployment rates in earlier times are supplemented by $M$ itchell (1998) and Layard (1991), where we use Layard (1991) as a priority. Only total unemployment rates are available for early years - consistent series unemployment rates broken down by gender or smaller geographic regions do not exist. Table Al reports the availability of the unemployment rates for different periods in specific countries. Using the overlapping years across sources we compute that the correlation coefficient between WDI and OECD is 0.99 , and that between M itchell's and Layard's series is 0.95 , indicating a high degree of consistency in 
unemployment rates across different sources. To capture the systematic differences across different sources, dummy variables for different data sources are applied throughout the analysis. Figure A 2 plots the unemployment rate for each country annually, showing a large variation across different countries and time periods.

Unemployment rates are not available for all countries and all years covered by the Eurobarometer. For example, many countries in the former Soviet Union only have unemployment data from the 1990s. In addition recall that not all waves collect all outcomes of interest. We are able to match individuals to unemployment rates at graduation for $94,77,76,81$, 78 and 74 percent of the samples with income, health, life satisfaction, obesity, smoking, and drinking respectively. Table $A 2$ reports the country availability for different outcome variables, as well as the weighted mean values for the whole and matched samples. The means in the matched and unmatched samples are very similar.

The matching process assumes that the country of current residence is the same as the country where the respondent was living in at the time of graduation. Unfortunately, there is no information in all the Eurobarometer data on migration. Based on the limited information in the data, we find that 93.1 percent of people were born in the same country as they are surveyed. Since the 5-year cross-state migration rate is 8.9 percent and the lifetime cross-state migration rate is 32 percent in the U nited States in 2000 (M olloy et al. 2011), one relative advantage of using European data is that the migration rate across countries is lower. To alleviate concerns over the timing of graduation and remove some measurement error in the unemployment rate, we use the three-year average moving unemployment rate in our primary analysis - the average of unemployment rates in the year of graduation, one year before and one year after.

To document the variation in unemployment rates that we use, Table 1 reports summary statistics for the unemployment rate and the residual unemployment rate, net of controls. The mean unemployment rate ranges from 6 to 8 percent across our different samples, with a standard deviation of 4.2-5 percent. If we regress unemployment rates on all controls, then we obtain the residual variation that identifies the effect of unemployment in our study. By construction these residuals have a mean of zero, but importantly, there is a lot of variation in unemployment rates net of country-specific trends and cohort effects: the standard deviation in these residuals is about 4 percent. 


\section{b. Empirical approach}

Following Oreopoulos et al. (2012), our main estimation strategy relates outcomes to personal characteristics, including education, unemployment rate at the time of finishing school, and the interaction between education and finishing school unemployment rates. It is this interaction term that indicates how education affects the return to a good or bad economy.

Clearly, estimating such a model needs controls for other factors that influence outcomes. Our first controls are for differences in cohorts over time. Graduation cohort effects $\left(\delta_{g}\right)$ and experience effects $\left(\delta_{\mathrm{e}}\right)$ pick up differences across cohorts dated by when they entered the labor market and labor market experience. Because the graduation cohort effects may vary over time and space, we allow for country-specific linear graduation time trends $\left(T_{c}\right)$. We al so control for education, the interaction between education and experience, and the impact of education and experience squared. This set of variables traces out average differences in outcomes by education over the lifecycle.

To control for current unemployment or other conditions across countries that may influence outcomes, we include country-survey year fixed effects $\left(\delta_{\mathrm{ct}}\right)$. Effectively, our identification is based on periods where unemployment is higher or lower than is typical for that country, controlling for the fact that cohorts differ on average and over time. The estimating equation is:

$$
\begin{aligned}
& Y_{i}=\beta_{0}+\beta_{1} U R_{c g}+\beta_{2} E d u_{i}+\beta_{3} U R_{c g} *\left(E d u_{i}-9\right)+\beta_{4} E d u_{i} * E x p_{i}+\beta_{5} E d u_{i} * \\
& \operatorname{Exp}_{i}^{2}+X_{i} \alpha+T_{c}+\delta_{e}+\delta_{g}+\delta_{c t}+\delta_{s}+\epsilon_{i}
\end{aligned}
$$

where $Y_{i}$ is the outcome for individual $i, U R_{c g}$ is the (three-year average) unemployment rate of graduation cohort $g$ in country $C_{,} E d_{i}$ is years of education, and $\operatorname{Exp}_{i}$ is years since graduation. $X_{i}$ is a set of control variables, including gender and marital status. $\delta_{\mathrm{s}}$ is a set of dummies for different source of unemployment data. Since unemployment rates are at the country-year level, we report standard errors clustered two ways, at the country-graduation cohort level, and at the country level.

In this model, $\beta_{1}$ shows how unemployment for a cohort with 9 years of education affects outcomes, and $\beta_{3}$ shows the differential response for the better educated. Recall that all of our outcomes are defined so that worse outcomes are a higher numerical value; thus, we expect $\beta_{1}>0$ 
(unemployment worsens outcomes) and $\beta_{3}<0$ (a smaller effect for the better educated). That said, the specific value of $\beta_{1}$ - the effect of unemployment on the less educated - is dependent on the value we choose for less educated ( 9 years, in this case). To illustrate the full range of effects, we plot the impact of unemployment on outcomes at different levels of education.

Although several outcomes of interest are dichotomous, we report OLS results for simplicity - results from probit or logit specifications are very similar when converted to marginal effects (A ppendix Table A 4). We estimate non-parametric models also.

\section{Empirical Results}

\section{a. Sample description and gradients in education}

Panels A and B of Table 1 show summary statistics across countries for each estimation sample. On average, 18 percent of the respondents reported poor health and 21 percent were dissatisfied with their lives. Eleven percent of the population is obese. Smoking is also popular, with 38 percent of respondent reporting smoking currently. Across the samples, the average years of education are stable, ranging from 12.1 to 12.6. There is also large variation in both education and outcome variables across countries. For example, the interquartile range across countries is 0.12 (67 percent of the mean value) for poor health, and about one sixth relative to the mean for education.

To document the variation in the effect of education across settings, we estimate the education gradient for each country by regressing the outcome of interest on education controlling for gender, marital status, age, and age-squared. Figure 1 plots these country-specific education gradients against the logarithm of GDP per capita. For example, Figure 1b plots education-health gradients and shows negative coefficients, indicating that higher education is associated with better health. The average gradients for all the other outcomes are also as expected. Education is positively associated with income (recall that higher income is a lower value), and negatively associated with life dissatisfaction.

[T able 1 about here]

[Figure 1 about here]

Even with these means, there is significant variation across countries. For example, the mean education gradient in smoking is -0.018 , but the interquartile range is 0.017 , almost the same magnitude. This variation is not particularly related to average current income, with the 
exception of income quartile (higher income countries have steeper gradients) and daily drinking (higher income countries have smaller gradients).

\section{b. Impact of Unemployment Rates in Early Adulthood}

Table 2 reports the OLS estimates of equation (1). We report the coefficients on unemployment at graduation $\left(\beta_{1}\right)$ and its interaction with education $\left(\beta_{3}\right)$ in the first two rows. The standard errors in parentheses are clustered at country-graduation cohort year level and those in brackets are clustered at country level. Panel A shows the results using three-year average unemployment rates around the time of graduation (the entire set of coefficients is displayed in the A ppendix Table A 3). Panel $B$ shows results using the unemployment rate in the year of graduation.

[T able 2 about here]

The coefficients in the first row indicate that higher unemployment when graduating is associated with lower socio-economic status and worse heath behaviors, consistent with the literature and findings in B ell and Blanchflower (2011) and M aclean (2013). The coefficients are large; for those with exactly 9-years of education, a 5 percentage point increase in unemployment is associated with a 3 percent greater likelihood of being unsatisfied with life relative to the mean $(0.05 * 0.122 / 0.21), 5$ percent greater likelihood of smoking $(0.05 * 0.411$ / $0.38)$, and a 12 percent greater likelihood of daily drinking $(0.05 * 0.203 / 0.08)$. The two exceptions to this pattern are general poor health status and obesity. In each case, unemployment is also associated with worse outcomes, though the estimates are not statistically significantly. Panel B reports the same results using unemployment rates in the exact year of graduation - the coefficients are similar but somewhat smaller, consistent with greater measurement error. In general unemployment and its interactions are jointly significant at the 10 percent level or higher ( $p$-values for joint test at bottom of table).

The sign on the interaction between schooling and unemployment rates is opposite to that on the unemployment rate: education plays a protective role when unemployment is high. For most outcomes, the coefficients are significant at 5 percent level. To see the heterogeneous effects more directly, Figure 2 plots the relationship between education and outcomes when unemployment is 4.6 and 9.6 percent, roughly corresponding to the annual unemployment rates

in US before and during the Great Recession, or to the $30^{\text {th }}$ and $70^{\text {th }}$ percentile of the unemployment rates distribution. Higher unemployment is associated with lower SES and worse 
health and health behaviors, especially for those with less education. For example, in figure 2e, we see that for those without formal schooling, a 4.6 percent unemployment rate is associated with a 2.5 percent probability of smoking, while a 9.6 percent unemployment rate is associated with 5.5 percent probability of smoking. For those with 15 years of education, the effect of greater unemployment is very small, less than 1 percent. Overall, the relationship between education and health is much steeper in bad times.

[Figures 2 about here]

Importantly, high unemployment raises the share of the less educated who are in poor health. Table 2 showed a non-significant impact of unemployment on self-reported poor health of those with 9 years of education. At education levels below that (about one-quarter of the sample), the impact of unemployment is markedly higher.

Previous literature documents important gender differences in the effects of recessions. For instance Hershbein (2012) finds no effects of graduating from high school in a recession for women's wages. However, Novo et al. $(2000,2001)$ find that women's heath decreases more than that of men during recessions in Sweden. Table 3 reports results separately for men and women. These are consistent with full sample results: the effect of unemployment is larger for lower education groups, though some of the coefficients are statistically insignificant. The bottom of the table tests the joint differences for the coefficients between men and women. Except for life dissatisfaction, we cannot reject equal ity of the coefficients across genders.

[Table 3 about here]

To investigate the relative short- and long-term impact of early life unemployment rates, we include the unemployment rate and its interaction with education with age group dummies ("younger" is a dummy for being aged 40 or less, and "older" is greater than 40). Table 4 shows that the "scarring" effect of high unemployment when graduating (and the protective effects of education) is driven primarily by younger cohorts, consistent with Oreopoulos et al. (2012). However the effects of unemployment on drinking and smoking are very similar across ages, consistent with high addictiveness.

The findings from Table 4 do not suggest a protective effect of early life unemployment at older ages. Hessel and A vendano (2013) find that economic recessions at the time of leaving school are associated with better health status in the later life using the SHA RE data. We suspect 
that our findings differ from theirs because we focus on working age individuals (up to age 55) whereas they look at those 50 and older.

[Table 4 about here]

\section{c. Functional form}

In A ppendix table A 8 we use education categories instead of linear years of schooling. Panel A reproduces our main results for reference. In panel B we show that the results are very similar if we use dummies for education categories rather than continuous years of education.

To further investigate non-linearities we estimate a non-parametric model. We do this in several steps. First, we estimate the education gradient in outcomes for each graduation cohort and country, with basic controls including marital status, gender and survey year dummies. We then regress the resulting gradients on linear and square terms of graduation years; the residuals are the gradient in education adjusted for a general time trend.

Figure 3 plots these adjusted residuals against unemployment residuals (from regressing unemployment rates when graduating on linear and square terms of graduation year). We estimate the relationship between the two using a kernel-weighted local polynomial. Generally, the patterns are consistent with our conclusions, but suggest the protective effects of education are largest when unemployment rates are high.

[Figure 3 about here]

\section{d. Endogenous Education}

If many people choose to remain in school or leave school because of business-cycle associated job prospects then our estimates might be biased. Oreopoulos et al. (2012) argue that the bias this behavior induces is small because the effect of unemployment on graduation timing is empirically small. We also find no statistically significant relationship between years of schooling and unemployment rates in our data (See the first column of A ppendix Table A6).

To further assess this extent of this bias, we follow the intuition in Kahn (2010) and Maclean (2013) and use unemployment around age 18 (median age at school completion) as a proxy for labor market conditions at time of graduation - if this unemployment rate precedes the decision on when to graduate it is independent of individual education's choices. Table 5 presents estimates using this alternative unemployment rate. A gain we find a large effect of 
unemployment at age 18 on outcomes that is smaller among the more educated (Panel A), and attenuated if we do not average over three years (Panel B).

\section{[Table 5 about here]}

A Iternatively we relate outcomes to the unemployment rates prevailing the first year individuals were allowed to drop out of school according to compulsory schooling laws- this is the last unemployment rate individuals observe before they can alter their education choices. The data on compulsory schooling laws across several (but not all) European countries and years can be found in the A ppendix Table of $G$ athmann et al. (2012).

Panel A of Table 6 first reports baseline results for the subset of country and cohorts for whom compulsory schooling laws are available. The coefficients on unemployment and its interaction with education are very similar to those in Table 2 , although a bit larger in magnitude. Panel B uses the unemployment rate at the "school-leaving age" instead. The magnitude and significance of the coefficients is very similar in both panels, although again slightly larger when we use the compulsory school law unemployment rates. Overall the results in Tables 5 and 6 suggest that the bias resulting from endogenous changes in the timing of graduation is negligible.

[Table 6 about here]

\section{e. The effect of contemporary recessions and recessions at the time of graduation}

Next we investigate how recessions at graduation differ from current recessions. We drop country-year survey dummies and instead control for the current unemployment rate and its interaction with education. Table 7 shows the results. Overall the direction and magnitude of the effects of graduating in a recession for low and high education groups remain the same (comparing these results to those in Panel A of Table 2) - the only important exception is life satisfaction, for which the effects of graduating in a recession become insignificant. Instead current unemployment rates lower satisfaction for all and more so for the uneducated.

[Table 7 about here]

The other coefficients generally confirm the literature that recessions are good for (current) health. Current unemployment is associated with better general health, less smoking, and less drinking. Thus we can replicate previous results showing that self-reported health and health behaviors improve in bad times, though the interactions with education suggest this improvement is smaller among the more educated. However we add to the story by showing that 
self-reported health and risky behaviors are worse for those graduating in recessions, so the pattern reverses over time. These findings suggest that individuals, particularly the low educated, cut down on "luxury expenses" (smoking, alcohol, deserts) in the short run, but this short term deprivation leads to long-term increases in consumption of these goods.

Although this result may seem puzzling at first, there are known mechanisms by which this happens, at least in the case of nutrition. Experimental evidence with rats shows that food deprivation lowers body weight in the short run but results in obesity in the long run ( $\mathrm{MCC}$ ance 1962). In humans this has also been observed among the survivors of famines, for instance see Painter et al. (2005). The current understanding of these effects is that the body responds to lack of nutrition by adapting to more efficiently extract calories and store fat thereafter, a phenomenon known as "metabolic syndrome". This mechanism is optimal if the deprivation continues, but results in obesity otherwise. Similarly alcohol and cigarette consumption might increase over the long run because individuals who cut down in bad times overcompensate in good times. Without panel data, we cannot investigate the dynamics of consumption from the time of graduation onwards. But clearly the short and long term effects of recessions are substantially different.

\section{f. The Overall Impact of Early Life Labor Markets}

To understand how much of the variation in the education gradients across countries could result from this early life heterogeneity, we perform a simulation. We start by estimating the impact of a year of education on each outcome. To do this, we predict the average outcome using the actual $X^{\prime}$ 's for each individual (which we term $\widehat{Y}_{e d u}^{1}$ ), and again after increasing each individual's education by one year (termed $\widehat{Y}_{e d u+1}^{1}$ ). The difference between these predictions, $\widehat{\Delta Y}^{1}=\widehat{Y}_{e d u+1}^{1}-\widehat{Y}_{e d u}^{1}$, is the education gradient, holding constant demographics. We average this gradient at the country level to form a country-specific gradient.

We then see how unemployment at the end of formal education affects this average. To do this, we set the unemployment rate for each cohort and country to the average across all cohorts and countries. We then predict again the average outcome for each individual using their actual education and after increasing education by one year. We term these $\widehat{\mathrm{Y}}_{e d u}^{2}$ and $\widehat{\mathrm{Y}}_{e d u+1}^{2}$.

The difference between these, $\widehat{\Delta \mathrm{Y}}^{2}=\widehat{\mathrm{Y}}_{e d u+1}^{2}-\widehat{\mathrm{Y}}_{e d u}^{2}$, is the education gradient that would have obtained in the country if the unemployment rate were not different from the average. 
Table 8 reports the differences of gradients across countries under the above two settings for each outcome. Column 1 shows the difference between the $90^{\text {th }}$ percentile of the gradient distribution across countries and the $10^{\text {th }}$ percentile under actual unemployment rates. Column 2 reports that difference under mean unemployment rates. Column 3 shows the ratio, which is consistently smaller than one, ranging from 0.59 to 0.92 . The smaller the ratio is, the larger portion can be explained by unemployment rates.

The results indicate that a sizeable portion of the cross-country variation in the education gradient can be attributed to differences in unemployment rates. This effect is largest for life satisfaction and income, with the ratio being 0.31 and 0.59 , but it is also large for drinking and smoking with the ratios being 0.77 and 0.72 , respectively. The overall effects on health and obesity are more modest, with ratios around 0.85 . Since we cannot estimate causal effects of education, these results are only suggestive, but they point to differences in labor market conditions as a potentially important explanation for the heterogeneity in the returns to school.

[Table 8 about here]

\section{Discussion}

U sing consistent measures across a large set of countries and cohorts, we document that education gradients in income, health, life satisfaction, obesity, smoking, and drinking vary substantially across countries. In this paper we explore one explanation for this variation in the returns to school. Both economic and epidemiology literatures show that early labor market conditions have a persistent effect on labor market outcomes. Individuals graduating in bad economic conditions earn substantially lower wages for several years compared to those graduating in good times. We examine whether differences in unemployment at the time individuals first enter the labor market explain some of the variation in the education gradient in income, self-reported health status, life satisfaction, obesity, smoking and drinking.

We find that higher unemployment at graduation is associated with lower household income, poorer general health, lower life satisfaction, and higher probability of obesity, smoking and everyday drinking later in life. Furthermore these negative effects are substantially smaller for those with more education. Our estimates suggest that 15 to 70 percent of the cross-country variation in the gradient is explained by economic conditions at the time of graduation that differ on average across countries, though the magnitude varies with the outcome. 
There are some limitations in our analysis. First, the relationship of education with outcomes is an association. Although compulsory schooling laws are available to us, there is not enough variation in these laws in our sample to estimate causal effects. We document that the effect of unemployment on outcomes varies significantly by education - whether education itself "causes" individuals to respond differently to unemployment rates remains an open question.

These results suggest that education levels can be used for targeting programs aimed at helping those most affected by adverse economic conditions. They do not however explain why recessions have a differential impact by education. We show unemployment at the time of graduation differentially influences incomes of the less educated- this translates into higher health and life satisfaction. Unemployment might differentially affects the probability of being married-we find this not to be the case however (the second column of A ppendix Table A6. Our results in Table 2 are very similar if we exclude marital status Appendix Table A7). Alternatively unemployment influences outcomes by increasing stress. Unfortunately, the Eurobarometer does not ask about stress. Understanding why recessions have larger effects on the less education is an important avenue for future research.

We investigate a possible reason why education gradients vary across time and placeone that explains a substantial but not all the variation in the education gradient. Of course, there are other possible reasons to expect heterogeneity in the impact of education. Differential adoption of health innovations over time by the more educated is another potential explanation for the variation we observe across cohorts. This was the case, for instance, with smoking cessation: the Surgeon General's report in 1964 (Bayne-J ones et al. 1964) resulted in larger effects of maternal education on infant health (A izer and Stroud 2010). Individual and family differences might also play an important role: the return to education could be higher or lower for those from wealthy backgrounds or with lower cognitive ability (K ane 1994). Finally as argued in Genda et al. (2010), differences across countries such as labor market institutions might mediate the impact of recessions by education.

Nevertheless our findings have some interesting implications. We find that labor market conditions early in life have a long-lasting effect on health as well as economic outcomes, and these effects cumulate. This finding is in line with Case et al. (2005), who document that family income gradients among children get larger as they age, and with Cunha and Heckman (2007) who theoretically and empirically investigate "dynamic complementarities" in investments in 
health and education. Our findings also suggest that dynamic life-cycle considerations are important in understanding socioeconomic differences in health status: the effects of contemporary shocks not only differ by education but emerge fully only after a few years. For instance we find that although recessions improve self-reported health, obesity, smoking and drinking in the short run, they are deleterious in the long run for these same outcomes, particularly for those with low education.

Our results suggest that policies that target youth unemployment might have particularly large payoffs over the long term in reducing health and income disparities. A $n$ interesting avenue for future research would determine if policies targeted to the young can attenuate the negative long term effects of recessions. The extent to which job training and other programs improve the labor market success of young uneducated individuals is hotly debated but it appears to be modest (Card et al. 2011); our results suggest that evaluations of these programs should include health and health behaviors as outcomes. They also suggest that non-labor market programs could help disadvantaged youth in bad economic times by, for instance, improving mental health and preventing the development of poor health habits.

Future research should replicate our results using objective measures of health such as mortality, and use these findings to quantify the overall impacts of recessions on health and health disparities over the life course. Subsequent research should also document the specific mechanisms by which the more educated are able to buffer themselves from recessions, and the extent to which policy can improve the outcomes of uneducated youth. This agenda is particularly important today, given that the Great Recession has had a very large and disproportionate impact on youth, and that our results suggest the impact of recessions of this magnitude is substantial. 


\section{References}

Bagnardi, V., Zambon, A., Quatto, P., \& Corrao, G. (2004). Flexible meta-regression functions for modeling aggregate dose-response data, with an application to alcohol and mortality. American J ournal of E pidemiology,159(11), 1077-1086.

Bansak, Cynthia, M ary E. Graham, and Allan A. Zebedee. 2012. "B usiness Cycles and Gender Diversification: An Analysis of Establishment-Level Gender Dissimilarity." American Economic Review, 102(3): 561-65.

Bayne-J ones, Stanhope, Walter J. B urdette, William G. Cochran, Emmanuel Farber, Louis F. Fieser, Jacob Furth, John B. Hickam, Charles LeM aistre, Leonard M. Schuman and M aurice H. Seevers. (1964) "Smoking and Health: Report of the A dvisory Committee to The Surgeon General of The Public Health Service." US Department of Health, Education, and W elfare, Public Health Service

Beland, Francois, Stephen Birch and Greg Stoddart. (2002) "Unemployment and health: contextual-level influences on the production of health in populations." Social Science \& Medicine 55: 2033-2052

Bell, David N. F. and David G. Blanchflower. (2011) "Y oung people and the Great Recession." Oxford Review of Economic Policy, V olume 27, Number 2, pp. 241-267

Borges-M endez, Ramon; Denhardt, Lillian; and Collett, Michelle (2013) "Global and Local Y outh Unemployment: Dislocation and Pathways," New England Journal of Public Policy: Vol. 25: Iss. 1, A rticle 7

B runello, G., Fabbri, D., \& Fort, M. (2013). The causal effect of education on body mass: Evidence from Europe. J ournal of Labor Economics, 31(1), 195-223.

Burkhauser, R. V., \& Cawley, J. (2008). B eyond B MI: the value of more accurate measures of fatness and obesity in social science research. J ournal of $\mathrm{H}$ ealth Economics, 27(2), 519529.

Card, D. (2001). Estimating the return to schooling: Progress on some persistent econometric 
problems. E conometrica, 69(5), 1127-1160.

Card, D., Ibarrarán, P., Regalia, F., Rosas-Shady, D., \& Soares, Y. (2011). The labor market impacts of youth training in the Dominican Republic. J ournal of Labor Economics, 29(2), 267-300.

Case, A nne, Angela Fertig and Christina Paxson. (2005) "The Lasting Impact of Childhood Health and Circumstance," J ournal of H ealth E conomics, 24, 365-389.

Di Castelnuovo, A., Costanzo, S., B agnardi, V., D onati, M. B., Iacoviello, L., \& de Gaetano, G. (2006). Alcohol dosing and total mortality in men and women: an updated meta-analysis of 34 prospective studies. Archives of internal medicine, 166(22), 2437-2445.

Clark, Damon and Heather Royer. (2013) "The Effect of Education on A dult M ortality and Health: Evidence from B ritain." American Economic Review, 103(6): 2087-2120

Cook, P. J., \& Moore, M. J. (2002). The economics of alcohol abuse and alcohol-control policies. Health affairs, 21(2), 120-133.

Cooper, Brian. (2011) "Economic Recession and Mental Health: an Overview." Neuropsychiatrie, 25: 113-117

Cunha, Flavio, and James Heckman. (2007) "The Technology of Skill Formation." American E conomic Review, 97(2): 31-47.

Cutler, David M., E.R. M eara and S. Richards, (2008) "The Gap Gets Bigger: Changes in M ortality and Life Expectancy by Education, 1981-2000," Health Affairs, 27(2): 350-360.

Cutler, David, and A driana Lleras-M uney. (2008) "Education and Health: Evaluating Theories and Evidence. In Making A mericans Healthier: Social and Economic Policy as Health Policy" J House, Schoeni, R, Kaplan, G, and Pollack, H. New York: Russell Sage Foundation.

Cutler, David. M. and A driana Lleras-M uney, (2010a) "The Education Gradient in Old Age Disability," in David W ise, ed., Research Findings in the Economics of A ging, Chicago: U niversity of Chicago Press, 101-120. 
Cutler, David M . and A . L leras-M uney, (2010b) "Understanding differences in health behaviors by education." J ournal of $\mathrm{H}$ ealth E conomics, 29(1), 1-28.

Cutler, David and Adriana Lleras-Muney. (2012) "Education and Health: Insights from International Comparisons." NBER W orking Paper 17738, January 2012

Deaton, A ngus, 2002. Policy implications of the gradient of health and wealth. Health Affairs 21 , 13-30.

Deaton, Angus S., Christina H. Paxson, 1998. A ging and inequality in income and health. The American Economic Review 88, 248-253.

Engemann, K ristie M. and Howard J. Wall. "The Effects of Recessions A cross Demographic Groups." F ederal Reserve Bank of St. Louis Review, 2010

Ettner, S. L. (1997). M easuring the human cost of a weak economy: Does unemployment lead to alcohol abuse?. Social Science \& M edicine, 44(2), 251-260.

Fischer, M ., Karlsson, M ., \& Nilsson, T. (2013). Effects of compulsory schooling on mortality: evidence from Sweden. International journal of environmental research and public health, 10(8), 3596-3618.

Fletcher, J.M ., J ody L. Sindelar, Y amaguchi, S., 2011. Cumulative effects of job characteristics on health. Health E conomics 20, 553-570.

Gathmann, Christina, with Hendrik Jürges and Steffen Reinhold (2012) "Compulsory Schooling and Mortality in 20th Century Europe," Social Science and M edicine, Special issue on "Educational A ttainment and A dult Health: Contextual izing Causality".

Genda, Y uji, A yako K ondo and Souichi Ohta. (2010) "Long-Term Effects of a Recession at Labor M arket Entry in Japan and the United States." The J ournal of Human Resources, 45:157-196

Gerdtham, U. G., \& Ruhm, C. J. (2006). Deaths rise in good economic times: evidence from the OECD. Economics \& Human Biology, 4(3), 298-316. 
Gibbons, Robert, Lawrence F. Katz, Thomas Lemieux, and Daniel Parent. 2005. "Comparative A dvantage, Learning, and Sectoral Wage Determination." J ournal of Labor Economics, 23(4): 681-723.

G mel, G., Gutjahr, E., \& Rehm, J. (2003). How stable is the risk curve between alcohol and allcause mortality and what factors influence the shape? A precision-weighted hierarchical meta-analysis. European journal of epidemiology, 18(7), 631-642.

Grossman, M . (1972). On the concept of health capital and the demand for health. The J ournal of Political Economy, 80(2), 223.

Hammarström, A. and U Janlert. (2002) "Early unemployment can contribute to adult health problems: results from a longitudinal study of school leavers." J Epidemiol Community Health 56: 624-630

Hessel, P., \& Avendano, M. (2013). A re economic recessions at the time of leaving school associated with worse physical functioning in later life?. Annals of epidemiology, 23(11), 708-715.

Hershbein, B rad (2012). "Persistence in labor supply effects of graduating in a recession: the case of high school women." The B.E. J ournal of Economic Analysis \& Policy, 12(1): 1935-1682

Jónsdóttir, S., \& Ásgeirsdóttir, T. L. (2013). The effect of job loss on body weight during an economic collapse. The E uropean J ournal of Health Economics, 1-10.

Idler, E. L., \& Benyamini, Y . (1997). Self-rated health and mortality: a review of twenty-seven community studies. J ournal of health and social behavior, 21-37.

K ahn, Lisa B. (2010) "The long-term labor market consequences of graduating from college in a bad economy." Labour Economics 17: 303-316

Kane, T. J. (1994). College entry by blacks since 1970: The role of college costs, family background, and the returns to education. J ournal of political Economy, 878-911. 
K unst A E and J P Mackenbach. (1994) "The size of mortality differences associated with educational level in nine industrialized countries." American J ournal of Public Health June 1994: Vol. 84, N 0. 6, pp. 932-937. doi: 10.2105/A JPH.84.6.932

Latham, K ., \& Peek, C. W . (2013). Self-rated health and morbidity onset among late midlife US adults. The Journals of Gerontology Series B: Psychological Sciences and Social Sciences, 68(1), 107-116.

Layard, Richard, Stephen Nickell and Richard Dackman. (1991) "Unemployment: M acroeconomic Performance and the L abour M arket" Oxford U niversity Press, USA

Lepper, H. S. (1998). Use of other-reports to validate subjective well-being measures. Social Indicators Research, 44(3), 367-379.

Lleras-M uney, A driana. (2005) "The Relationship between Education and A dult M ortality in the United States." The Review of Economic Studies, 72(1): 189-221

Lundin, Andreas and Tomas Hemmingsson. "Adolescent predictors of unemployment and disability pension across the life course - a longitudinal study of selection in 49321 Swedish men", Institute for Evaluation of Labour M arket and Education Policy W orking paper, 2013:25

M aclean, J ohanna Catherine. (2013) "The health effects of leaving school in a bad economy." J ournal of Health E conomics 32: 951- 964

M artinez, D. J., Kasl, S. V., Gill, T. M ., \& Barry, L. C. (2010). Longitudinal association between self-rated health and timed gait among older persons. The J ournals of G erontology Series B: Psychological Sciences and Social Sciences, 65(6), 715-719.

M ccance, R.A. (1962) "Food, Growth, A nd Time" The Lancet, 280(7258): 671-676

Meghir, C., Palme, M., \& Simeonova, E. (2013). Education, Cognition and Health: Evidence from a Social Experiment (N o. w19002). National B ureau of Economic Research.

Mitchell, Brian R. (1998) International Historical Statistics: Europe, 1750-1993, Palgrave Macmillan; 4th edition 
M olloy, R., Smith, C. L., \& W ozniak, A. (2011). Internal M igration in the United States. J ournal of E conomic Perspectives, 25(3), 173-96.

M ontgomery, S. M., Cook, D. G., B artley, M. J., \& Wadsorth, M. E. (1998). Unemployment, cigarette smoking, alcohol consumption and body weight in young British men. The European J ournal of Public Health, 8(1), 21-27.

Novo, M., Hammarstrom, A., and Janlert, U. (2000). Health hazards of unemployment only a boom phenomenon? A study of young men and women during times of prosperity and times of recession. Public H ealth, 114: 25-29.

Novo, M., Hammarström, A., \& Janlert, U. (2001). Do high levels of unemployment influence the health of those who are not unemployed? A gendered comparison of young men and women during boom and recession.Social science \& medicine, 53(3), 293-303.

Organization For Economic Co-operation and Development Statistics: http://stats.oecd.org/

Oreopoulos, Philip, Till von Wachter, and Andrew Heisz. (2012) "The Short- and Long-Term Career Effects of Graduating in a Recession." American Economic Journal: Applied Economics, 4(1): 1-29.

Oyer, Paul, 2006. Initial labor market conditions and long-term outcomes for economists. The J ournal of E conomic Perspectives 20, 143-160.

Painter, Rebecca C., Tessa J. Roseboom and Otto P. Bleker (2005). "Prenatal exposure to the Dutch famine and disease in later life: An overview", Reproductive Toxicology , pp. 345-352.

Psacharopoulos, G., \& Patrinos, H. A. (2004). Returns to investment in education: a further update. Education economics, 12(2), 111-134.

Reeves, A., Stuckler, D., M cK ee, M., Gunnell, D., Chang, S. S., \& Basu, S. (2012). Increase in state suicide rates in the USA during economic recession.The Lancet, 380(9856), 18131814. 
Ruhm, C. J. (1995). Economic conditions and alcohol problems.Journal of health economics, 14(5), 583-603.

Ruhm, C. J., \& Black, W. E. (2002). Does drinking really decrease in bad times?. J ournal of Health E conomics, 21(4), 659-678.

Ruhm, C. J. (2003). Good times make you sick. J ournal of health economics,22(4), 637-658.

Sander, William. (1994) "Schooling and Quitting Smoking." The Review of Economics and Statistics 77(1): 191-199

Sandvik, E., Diener, E., \& Seidlitz, L. (1993). Subjective well-being: The convergence and stability of self-report and non self-report measures. J ournal of Personality, 61(3), 317342.

Stuckler, D., Basu, S., Suhrcke, M., Coutts, A., \& McKee, M. (2011). Effects of the 2008 recession on health: a first look at European data. The L ancet, 378(9786), 124-125.

Topel, Robert H., and Michael P. W ard. 1992. "Job M obility and the Careers of Y oung M en." Q uarterly J ournal of E conomics, 107(2): 439-79.

Wadsworth, M .E.J., S.M . M ontgomery and M .J. B artley. (1999) Social Science \& M edicine 48: 1491-1499

White, I. R., Altmann, D. R., \& Nanchahal, K. (2002). A lcohol consumption and mortality: modelling risks for men and women at different ages. B mj, 325(7357), 191.

W orld Development Indicators, The W orld B ank, http://data.worldbank.org/ , 29 M ay, 2013. 
Figure 1: Education Gradients across Countries by Outcomes
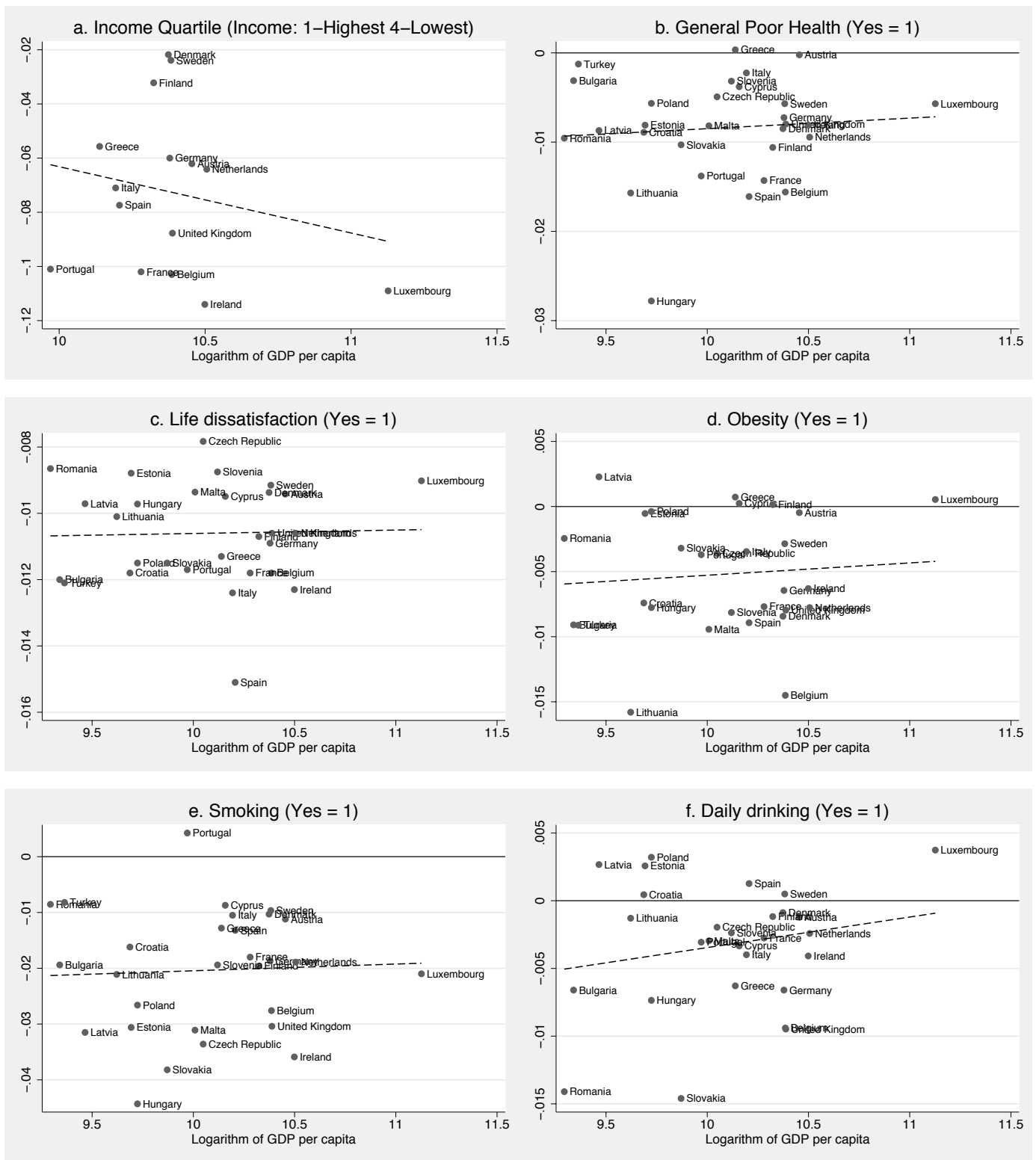

Note: Each dot represents the coefficient of education from a country-level individual regression of outcome on education and basic covariates. 
Figure 2: Impact of Education on Outcomes, For Different Levels of Unemployment
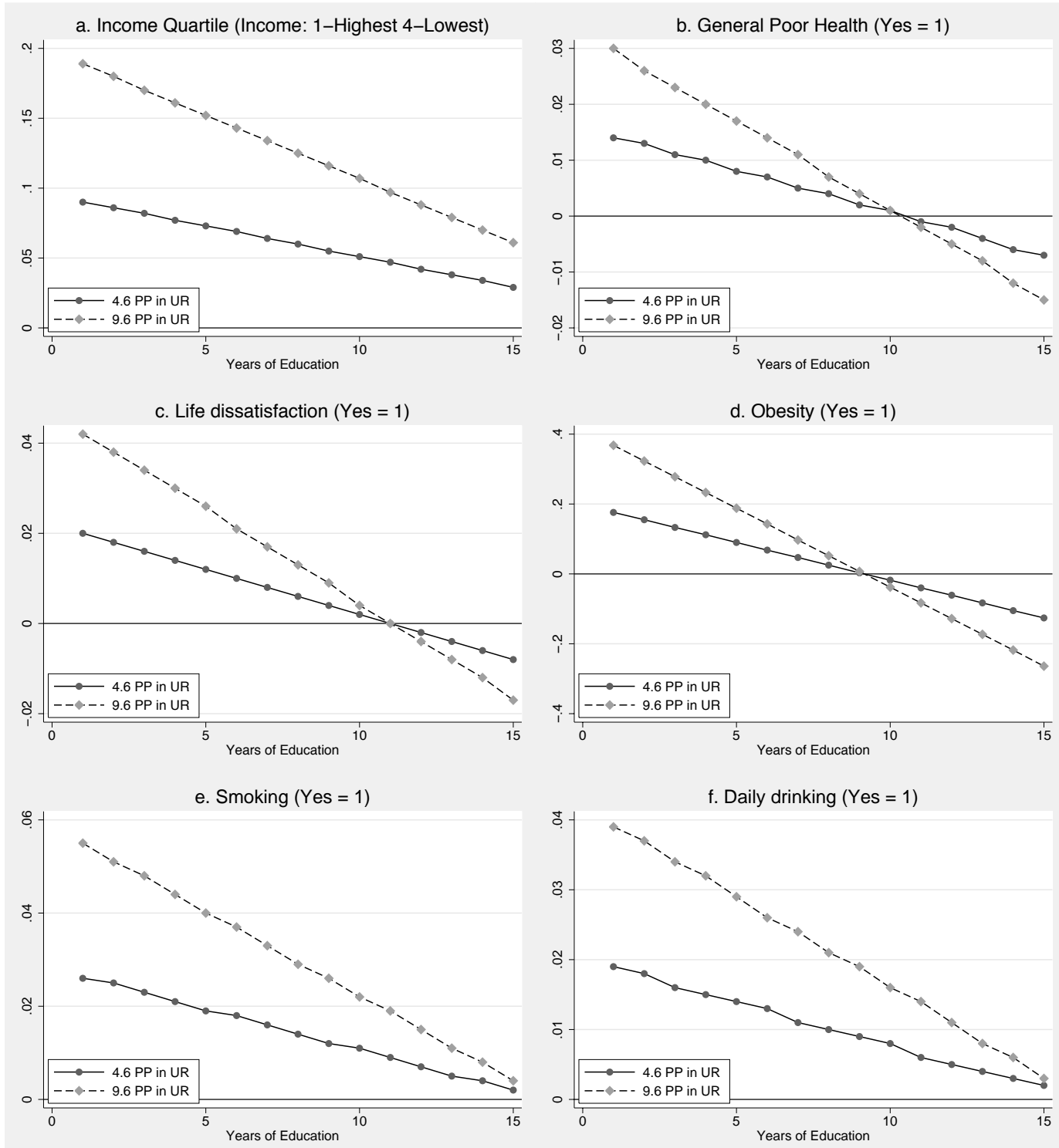

Note: Solid lines and dashed lines are predicted outcomes based on the coefficients in Panel A of Table 2 for 4.6 and 9.6 percentage points in unemployment rates, respectively. 
Figure 3: Non-parametric Estimation - Residuals of Education Gradients against Residuals of Unemployment Rates
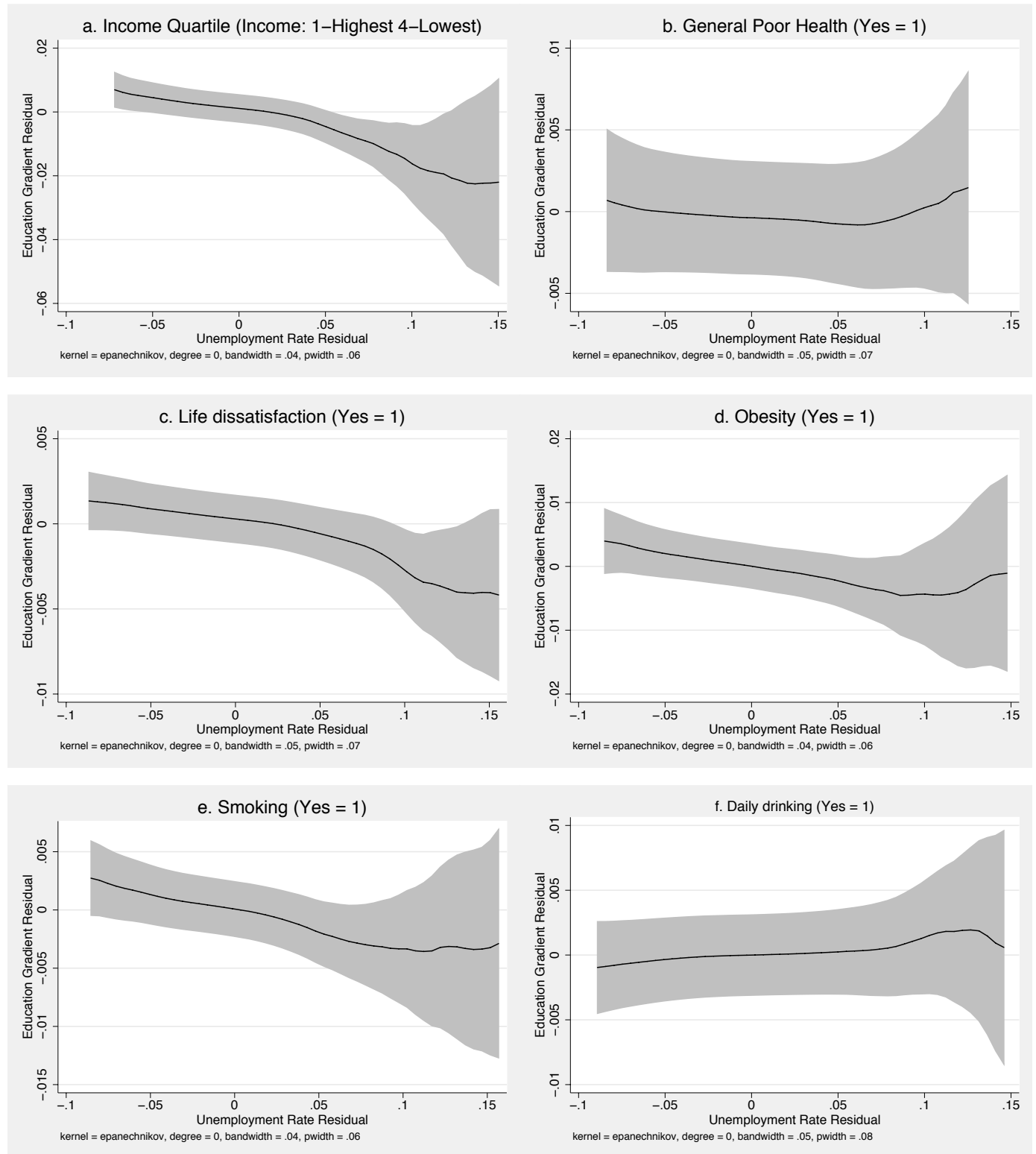

Note: Residuals of Y-Axis are from regressing gradients for each graduation cohort and country, on linear and square terms of graduation years. The residuals of X-Axis are residuals from regressing unemployment rates in year of graduation on linear and square terms of graduation year. 
Figure A1: Comparison of Education from Different Sources

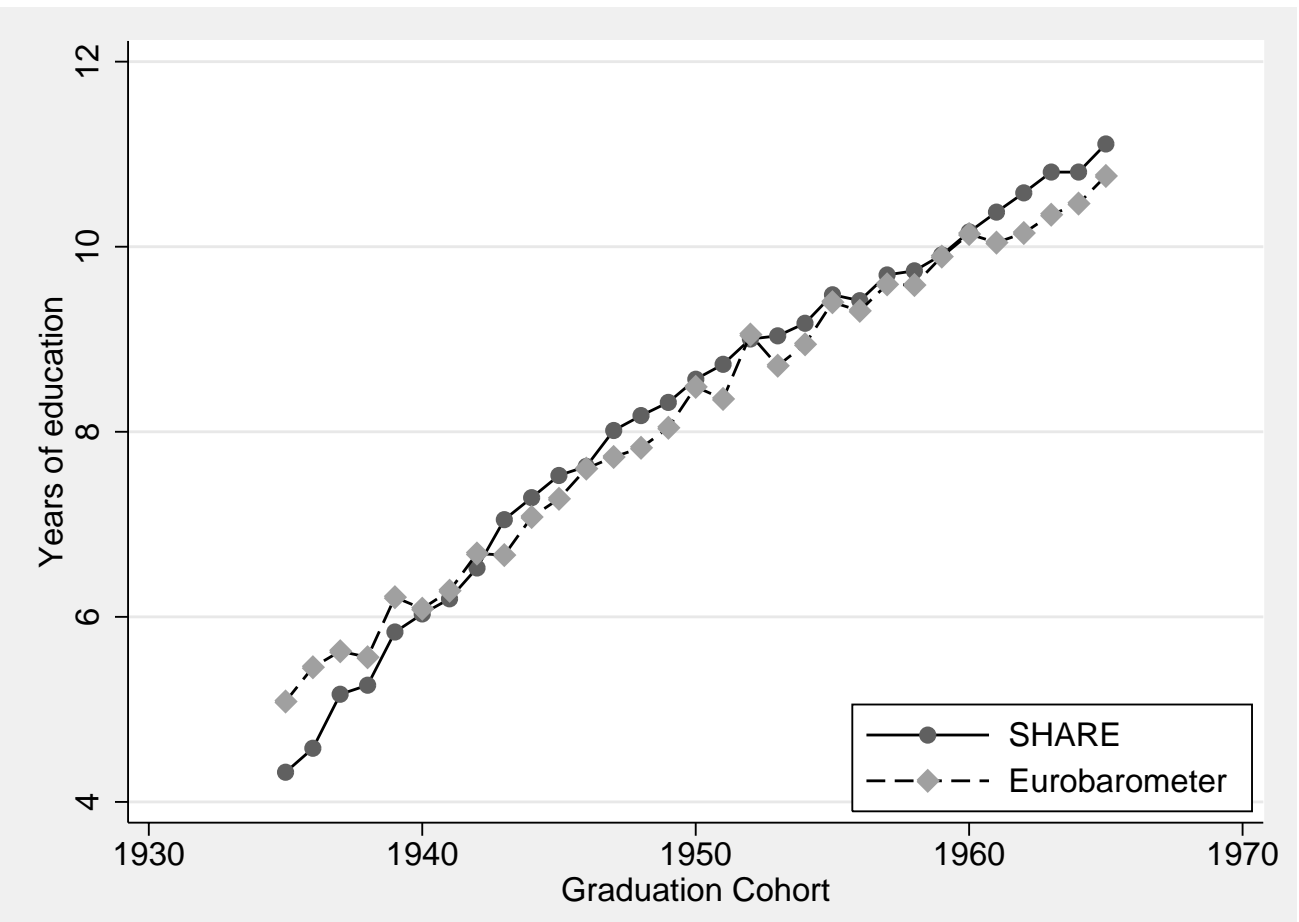

(a) Years of education against graduation cohort, by data source

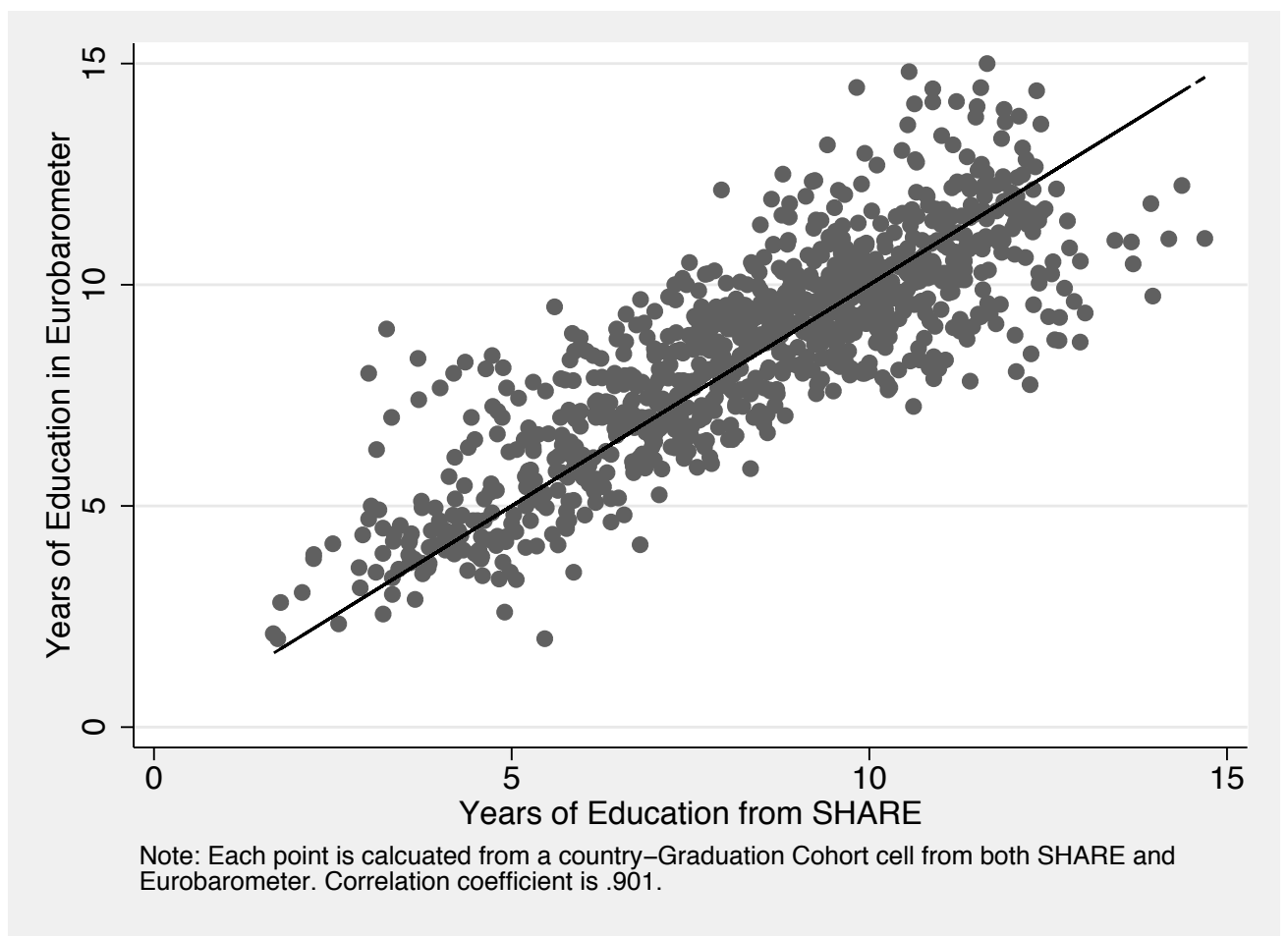

(b) Years of education in Eurobarometer against years of education in SHARE 
Figure A2: Unemployment Rates against Year, by Country

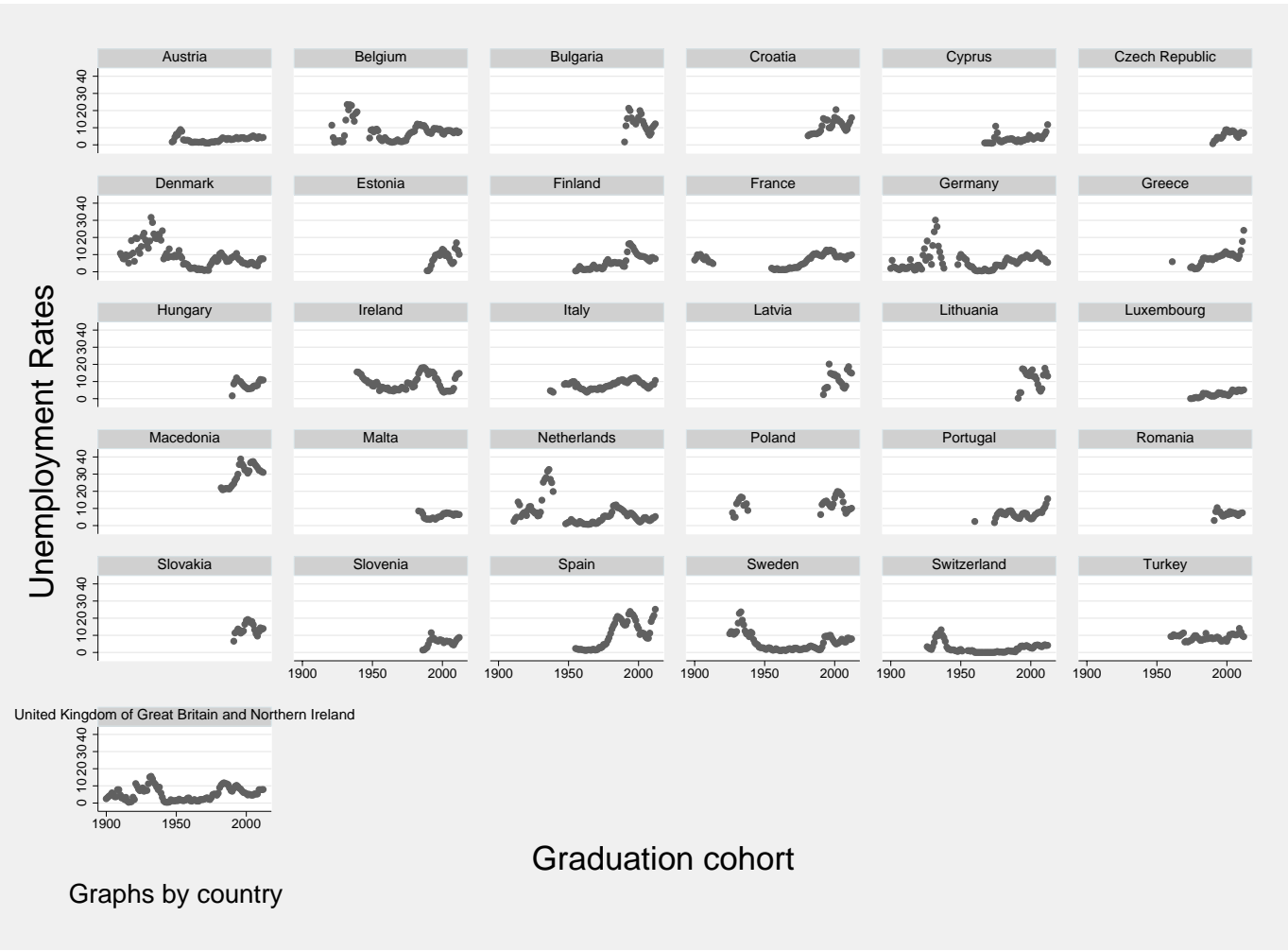



(1)
$(2)$
(3)
(4)
(5)
(6)

Sample

Income sample Health sample dissatisfaction Obesity sample Smoke sample Drink sample sample

Panel A: Dependent variable

\section{Mean}

Standard deviation

Interquartile range across countries

Panel B: Years of education

Mean

Standard deviation

Interquartile range across countries

1.91

12.32

(4.09)

2.09

0.18

(0.38)

0.12

0.21

(0.41)

0.21

12.53

(4.10)

2.08

12.24

(4.17)

1.75

0.11

(0.31)

0.11

$(0.49)$

0.08

$(0.27)$

0.06

\section{Panel C: Unemployment rates}

\begin{tabular}{|c|c|c|c|c|c|c|}
\hline Mean & 0.058 & 0.070 & 0.080 & 0.070 & 0.076 & 0.075 \\
\hline Standard deviation & $(0.042)$ & $(0.045)$ & $(0.050)$ & $(0.045)$ & $(0.048)$ & $(0.045)$ \\
\hline Standard deviation of residual UR & $(0.039)$ & $(0.040)$ & $(0.045)$ & $(0.041)$ & $(0.043)$ & $(0.040)$ \\
\hline Observations & 50,590 & 28,411 & 87,407 & 17,765 & 47,818 & 19,632 \\
\hline Years of Eurobaometer & $1997-2003$ & 2002, 2006 & $\begin{array}{c}2005,2006, \\
2009,2011, \\
2012\end{array}$ & 2003,2005 & $\begin{array}{c}2002,2005, \\
2006,2009, \\
2011,2012\end{array}$ & 2006, 2009 \\
\hline Eurobarometer data source & $\begin{array}{c}47.2,49.0,52.1, \\
53.0,55.0,56.1 \\
57.0,58.259 .0\end{array}$ & $58.2,64.3,66.2$ & $\begin{array}{c}63.4,64.2,66.3 \\
71.2,76.3,77.3 \\
77.4,78.1\end{array}$ & $59.0,64.3$ & $\begin{array}{c}58.2,64.1,66.2 \\
72.3,77.1\end{array}$ & $66.2,72.3$ \\
\hline
\end{tabular}

Note: Standard deviations in parentheses. The residual unemployment rates are from regressing unemployment rates when graduating on indicators for gender, marital status, graduation cohorts, years since graduation, UR sources, countries, survey years, country interacting with survey years and linear time trends for specific country. 
Table 2: Education, Unemployment Rate and Outcomes in Eurobarometer

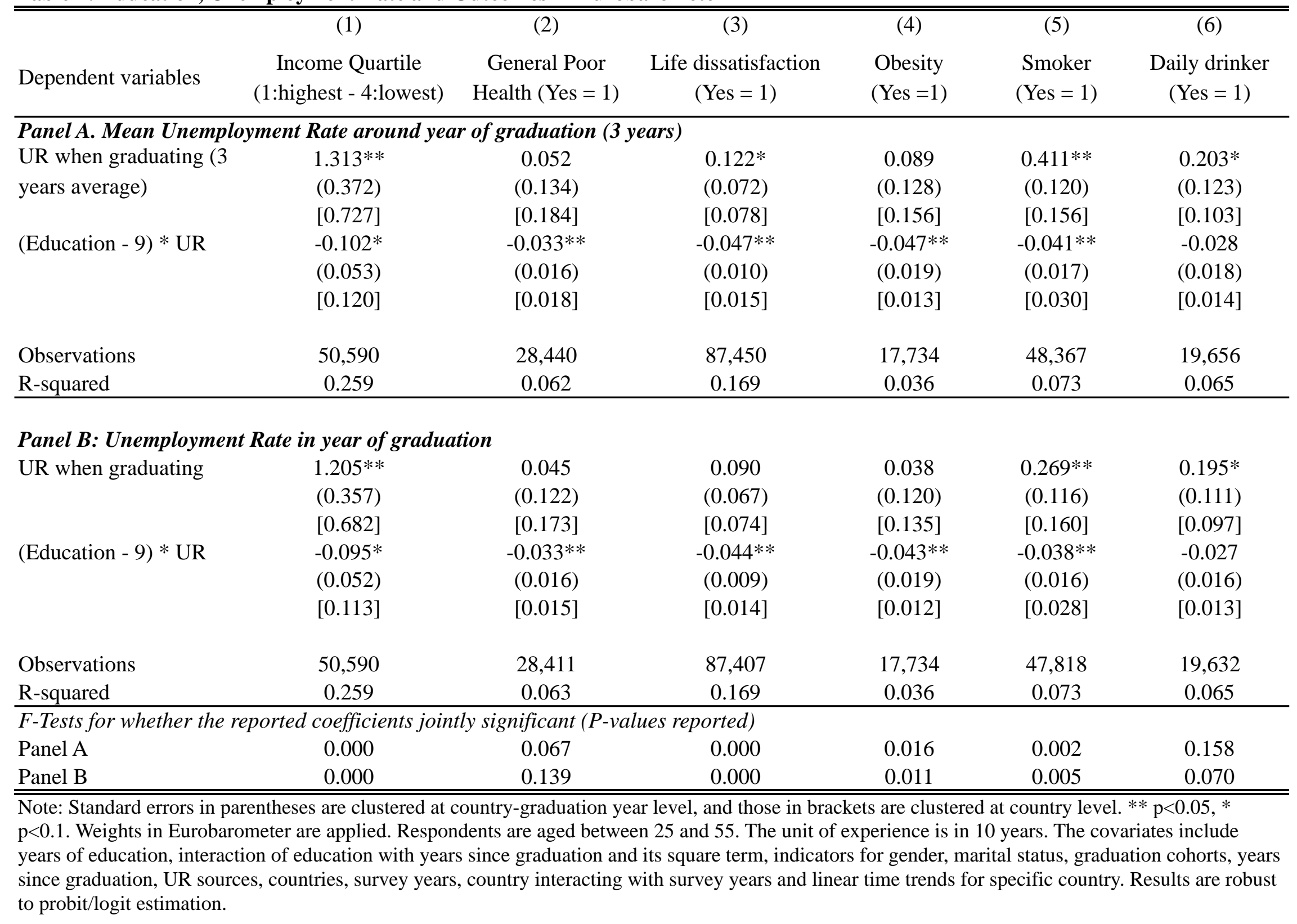


Table 3: Education, Unemployment Rate and Outcomes in Eurobarometer, by Gender

\begin{tabular}{|c|c|c|c|c|c|c|}
\hline Dependent variables & $\begin{array}{c}\text { (1) } \\
\text { Income Quartile } \\
\text { (1:highest - 4:lowest) }\end{array}$ & $\begin{array}{c}(2) \\
\text { General Poor } \\
\text { Health (Yes = 1) }\end{array}$ & $\begin{array}{c}(3) \\
\text { Life dissatisfaction } \\
(\text { Yes }=1)\end{array}$ & $\begin{array}{c}(4) \\
\text { Obesity } \\
(\text { Yes = 1) }\end{array}$ & $\begin{array}{c}(5) \\
\text { Smoker } \\
(\text { Yes = 1) }\end{array}$ & $\begin{array}{c}(6) \\
\text { Daily drinker } \\
(\text { Yes }=1)\end{array}$ \\
\hline \multicolumn{7}{|l|}{ Panel A: Male sample } \\
\hline UR when graduating (3 & $1.612 * *$ & 0.075 & $0.273 * *$ & -0.182 & $0.352 * *$ & $0.379 *$ \\
\hline \multirow[t]{2}{*}{ years average) } & $(0.488)$ & $(0.208)$ & $(0.104)$ & $(0.213)$ & $(0.173)$ & $(0.205)$ \\
\hline & {$[0.743]$} & [0.299] & [0.084] & {$[0.231]$} & {$[0.212]$} & {$[0.187]$} \\
\hline \multirow[t]{3}{*}{$($ Education -9$) * \mathrm{UR}$} & -0.074 & -0.023 & $-0.068 * *$ & -0.028 & -0.025 & -0.043 \\
\hline & $(0.059)$ & $(0.026)$ & $(0.013)$ & $(0.027)$ & $(0.025)$ & $(0.029)$ \\
\hline & {$[0.113]$} & {$[0.031]$} & {$[0.016]$} & [0.028] & [0.037] & {$[0.025]$} \\
\hline Observations & 24,457 & 12,792 & 39,650 & 8,146 & 21,538 & 8,640 \\
\hline R-squared & 0.229 & 0.075 & 0.171 & 0.045 & 0.075 & 0.066 \\
\hline \multicolumn{7}{|l|}{ Panel B: Female sample } \\
\hline UR when graduating (3 & $0.883 *$ & 0.017 & -0.063 & $0.302 *$ & $0.444 * *$ & 0.047 \\
\hline \multirow{2}{*}{ years average) } & $(0.526)$ & $(0.176)$ & $(0.096)$ & $(0.171)$ & $(0.151)$ & $(0.114)$ \\
\hline & {$[0.796]$} & {$[0.162]$} & {$[0.116]$} & {$[0.207]$} & {$[0.191]$} & [0.096] \\
\hline \multirow[t]{3}{*}{$($ Education -9$) * \mathrm{UR}$} & $-0.129 *$ & -0.035 & $-0.027 * *$ & $-0.069 * *$ & $-0.053 * *$ & -0.015 \\
\hline & $(0.072)$ & $(0.024)$ & $(0.012)$ & $(0.026)$ & $(0.019)$ & $(0.014)$ \\
\hline & {$[0.144]$} & {$[0.018]$} & {$[0.018]$} & {$[0.030]$} & {$[0.025]$} & {$[0.010]$} \\
\hline Observations & 26,133 & 15,648 & 47,800 & 9,588 & 26,829 & 11,016 \\
\hline R-squared & 0.306 & 0.071 & 0.176 & 0.056 & 0.068 & 0.034 \\
\hline \multicolumn{7}{|c|}{ Joint tests for relevant coefficients in Panel A are the same as those in Panel B } \\
\hline Chi-2 statistics & 3.42 & 0.16 & 9.97 & 3.32 & 0.55 & 1.55 \\
\hline P-value & 0.181 & 0.93 & 0.01 & 0.19 & 0.76 & 0.46 \\
\hline
\end{tabular}


Table 4. Education, Unemployment Rates and Outcomes in Different Age Groups

\begin{tabular}{|c|c|c|c|c|c|c|}
\hline Dependent variables & $\begin{array}{c}(1) \\
\text { Income Quartile } \\
\text { (1:highest - 4:lowest) }\end{array}$ & $\begin{array}{c}(2) \\
\text { General Poor } \\
\text { Health }(\text { Yes = 1) }\end{array}$ & $\begin{array}{c}(3) \\
\text { Life dissatisfaction } \\
(\text { Yes }=1)\end{array}$ & $\begin{array}{c}(4) \\
\text { Obesity } \\
(\text { Yes }=1)\end{array}$ & $\begin{array}{c}(5) \\
\text { Smoker } \\
(\text { Yes = 1) }\end{array}$ & $\begin{array}{c}(6) \\
\text { Daily drinker } \\
(\text { Yes = 1) }\end{array}$ \\
\hline \multirow[t]{3}{*}{ UR * (Ages 25-40) } & $1.620 * *$ & 0.065 & $0.187 * *$ & 0.088 & $0.417 * *$ & 0.197 \\
\hline & $(0.372)$ & $(0.133)$ & $(0.076)$ & $(0.129)$ & $(0.123)$ & $(0.123)$ \\
\hline & {$[0.707]$} & {$[0.183]$} & {$[0.097]$} & {$[0.161]$} & {$[0.188]$} & {$[0.112]$} \\
\hline$($ Education -9$) *$ UR $*$ & $-0.217 * *$ & $-0.052 * *$ & $-0.079 * *$ & $-0.052 * *$ & $-0.078 * *$ & $-0.034^{*}$ \\
\hline \multirow[t]{2}{*}{$($ Ages $25-40)$} & $(0.054)$ & $(0.017)$ & $(0.011)$ & $(0.020)$ & $(0.018)$ & $(0.018)$ \\
\hline & {$[0.120]$} & {$[0.017]$} & {$[0.018]$} & {$[0.018]$} & {$[0.036]$} & [0.014] \\
\hline \multirow[t]{3}{*}{ UR * (Ages 40-55) } & $-1.912 * *$ & -0.003 & -0.065 & -0.025 & $0.419 * *$ & 0.227 \\
\hline & $(0.573)$ & $(0.197)$ & $(0.097)$ & $(0.209)$ & $(0.172)$ & $(0.177)$ \\
\hline & {$[0.996]$} & [0.192] & [0.112] & [0.208] & {$[0.239]$} & {$[0.173]$} \\
\hline$($ Education -9$) *$ UR $*$ & $0.445 * *$ & -0.001 & 0.002 & -0.030 & 0.001 & -0.022 \\
\hline \multirow[t]{2}{*}{ (Ages 40-55) } & $(0.073)$ & $(0.024)$ & $(0.012)$ & $(0.028)$ & $(0.022)$ & $(0.021)$ \\
\hline & {$[0.152]$} & {$[0.022]$} & {$[0.015]$} & {$[0.022]$} & {$[0.039]$} & [0.019] \\
\hline Observations & 50,590 & 28,440 & 87,450 & 17,734 & 48,367 & 19,656 \\
\hline R-squared & 0.263 & 0.063 & 0.170 & 0.038 & 0.073 & 0.065 \\
\hline
\end{tabular}


Table 5. Education, Unemployment Rates When Aged 18 and Outcomes

\begin{tabular}{|c|c|c|c|c|c|c|}
\hline Dependent variables & $\begin{array}{c}\text { (1) } \\
\text { Income Quartile } \\
\text { (1:highest - 4:lowest) }\end{array}$ & $\begin{array}{c}\text { (2) } \\
\text { General Poor } \\
\text { Health }(\text { Yes = 1) } \\
\end{array}$ & $\begin{array}{c}(3) \\
\text { Life dissatisfaction } \\
(\text { Yes }=1)\end{array}$ & $\begin{array}{c}(4) \\
\text { Obesity } \\
(\text { Yes }=1)\end{array}$ & $\begin{array}{c}(5) \\
\text { Smoker } \\
(\text { Yes = 1) }\end{array}$ & $\begin{array}{c}(6) \\
\text { Daily drinker } \\
(\text { Yes }=1)\end{array}$ \\
\hline \multicolumn{7}{|c|}{ Panel A: Mean UR at age 17-19 } \\
\hline \multirow{2}{*}{ Mean UR at age $17-19$} & $(0.352)$ & $(0.130)$ & $(0.071)$ & $(0.128)$ & $(0.126)$ & $(0.103)$ \\
\hline & {$[0.890]$} & {$[0.160]$} & {$[0.120]$} & {$[0.099]$} & {$[0.203]$} & {$[0.107]$} \\
\hline \multirow[t]{2}{*}{ (Education - 9)* UR at 18} & $-0.395 * *$ & $-0.047 * *$ & $-0.059 * *$ & $-0.035 * *$ & $-0.069 * *$ & -0.013 \\
\hline & {$[0.154]$} & {$[0.018]$} & {$[0.017]$} & {$[0.012]$} & {$[0.034]$} & {$[0.017]$} \\
\hline Observations & 50,291 & 27,927 & 85,773 & 17,451 & 47,621 & 19,290 \\
\hline R-squared & 0.261 & 0.063 & 0.170 & 0.035 & 0.073 & 0.066 \\
\hline \multicolumn{7}{|l|}{ Panel B: UR at age 18} \\
\hline \multirow{2}{*}{$($ Education -9$) *$ UR at 18} & $(0.051)$ & $(0.015)$ & $(0.009)$ & $(0.015)$ & $(0.015)$ & $(0.015)$ \\
\hline & {$[0.142]$} & {$[0.017]$} & {$[0.016]$} & {$[0.012]$} & {$[0.032]$} & {$[0.015]$} \\
\hline Observations & 50,215 & 27,723 & 85,125 & 17,334 & 47,317 & 19,127 \\
\hline R-squared & 0.261 & 0.063 & 0.171 & 0.036 & 0.073 & 0.066 \\
\hline
\end{tabular}


Table 6. Unemployment Rates at Age Required by Compulsory Schooling Laws (CSLs) and Outcomes

\begin{tabular}{|c|c|c|c|c|c|c|}
\hline Dependent variables & $\begin{array}{c}\text { (1) } \\
\text { Income Quartile } \\
\text { (1:highest - 4:lowest) }\end{array}$ & $\begin{array}{c}(2) \\
\text { General Poor } \\
\text { Health }(\text { Yes = 1) } \\
\end{array}$ & $\begin{array}{c}\text { (3) } \\
\text { Life dissatisfaction } \\
(\text { Yes }=1)\end{array}$ & $\begin{array}{c}(4) \\
\text { Obesity } \\
(\text { Yes = 1) }\end{array}$ & $\begin{array}{c}(5) \\
\text { Smoker } \\
(\text { Yes }=1) \\
\end{array}$ & $\begin{array}{c}\text { (6) } \\
\text { Daily drinker } \\
(\text { Yes }=1)\end{array}$ \\
\hline \multicolumn{7}{|c|}{ Panel A: Unemployment rate in year of graduation } \\
\hline \multirow[t]{3}{*}{ Unemployment rate } & $1.849 * *$ & $0.286^{*}$ & $0.233 * *$ & $0.341 * *$ & $0.687 * *$ & 0.056 \\
\hline & $(0.411)$ & $(0.168)$ & $(0.101)$ & $(0.168)$ & $(0.150)$ & $(0.182)$ \\
\hline & {$[0.670]$} & {$[0.254]$} & {$[0.082]$} & [0.203] & {$[0.239]$} & [0.166] \\
\hline \multirow[t]{3}{*}{$($ Education -9$) * \mathrm{UR}$} & $-0.254 * *$ & $-0.060 * *$ & $-0.057 * *$ & $-0.042 *$ & $-0.086 * *$ & -0.028 \\
\hline & $(0.063)$ & $(0.022)$ & $(0.012)$ & $(0.024)$ & $(0.023)$ & $(0.027)$ \\
\hline & [0.123] & [0.026] & [0.016] & [0.022] & [0.043] & [0.021] \\
\hline Observations & 31,622 & 14,498 & 36,871 & 9,348 & 23,391 & 9,167 \\
\hline R-squared & 0.271 & 0.064 & 0.070 & 0.042 & 0.078 & 0.071 \\
\hline \multicolumn{7}{|c|}{ Panel B: Unemployment rate at the least graduation age required by CSLs } \\
\hline \multirow[t]{3}{*}{ Unemployment rate } & $1.534 * *$ & $0.327 * *$ & $0.182 * *$ & $0.297 *$ & 0.067 & 0.038 \\
\hline & $(0.401)$ & $(0.162)$ & $(0.091)$ & $(0.169)$ & $(0.174)$ & $(0.185)$ \\
\hline & {$[0.820]$} & {$[0.183]$} & {$[0.112]$} & {$[0.210]$} & {$[0.294]$} & [0.207] \\
\hline \multirow[t]{3}{*}{$($ Education -9$) * \mathrm{UR}$} & $-0.436 * *$ & $-0.063 * *$ & $-0.065 * *$ & $-0.046^{* *}$ & $-0.138 * *$ & -0.013 \\
\hline & $(0.061)$ & $(0.019)$ & $(0.011)$ & $(0.021)$ & $(0.021)$ & $(0.020)$ \\
\hline & {$[0.158]$} & {$[0.023]$} & {$[0.010]$} & {$[0.027]$} & {$[0.053]$} & [0.013] \\
\hline Observations & 31,622 & 14,498 & 36,871 & 9,348 & 23,391 & 9,167 \\
\hline R-squared & 0.273 & 0.064 & 0.071 & 0.042 & 0.079 & 0.071 \\
\hline
\end{tabular}

Note: Standard errors in parentheses are clustered at country-graduation year level, and those in brackets are clustered at country level. ** $p<0.05, * \mathrm{p}<0.1$. Weights in Eurobarometers are applied. Respondents are aged between 25 and 55. The unit of experience is in 10 years. The covariates include years of education, interaction of education with years since graduation and its square term, indicators for married, graduation cohorts, years since graduation, UR sources, countries, survey years, country interacting with survey years and linear time trends for specific country. Results are robust to (ordered) probit/logit estimation. The countries in this table include Austria, Belgium, Denmark, France, Ireland, Netherlands, Spain, Sweden and United Kingdom. 
Table 7: Education, Unemployment Rates and Outcomes in Eurobarometer, with Current Unemployment Rates included

\begin{tabular}{|c|c|c|c|c|c|c|}
\hline Dependent variables & $\begin{array}{c}\text { (1) } \\
\text { Income Quartile } \\
\text { (1:highest - 4:lowest) }\end{array}$ & $\begin{array}{c}(2) \\
\text { General Poor } \\
\text { Health (Yes = 1) }\end{array}$ & $\begin{array}{c}(3) \\
\text { Life } \\
\text { dissatisfaction } \\
(\text { Yes }=1) \\
\end{array}$ & $\begin{array}{c}(4) \\
\text { Obesity } \\
(\text { Yes }=1)\end{array}$ & $\begin{array}{c}(5) \\
\text { Smoker } \\
(\text { Yes = 1) }\end{array}$ & $\begin{array}{c}(6) \\
\text { Daily drinker } \\
(\text { Yes }=1)\end{array}$ \\
\hline $\begin{array}{l}\text { UR when graduating ( } 3 \text { years } \\
\text { average) }\end{array}$ & $\begin{array}{l}0.737 * \\
(0.382)\end{array}$ & $\begin{array}{c}0.053 \\
(0.133)\end{array}$ & $\begin{array}{l}-0.034 \\
(0.077)\end{array}$ & $\begin{array}{c}0.103 \\
(0.131)\end{array}$ & $\begin{array}{c}0.582 * * \\
(0.142)\end{array}$ & $\begin{array}{l}0.240^{*} \\
(0.124)\end{array}$ \\
\hline$($ Education -9$) *$ UR & $\begin{array}{c}-0.125 * * \\
(0.059)\end{array}$ & $\begin{array}{c}-0.039 * * \\
(0.017)\end{array}$ & $\begin{array}{l}-0.007 \\
(0.012)\end{array}$ & $\begin{array}{c}-0.057 * * \\
(0.022)\end{array}$ & $\begin{array}{c}-0.079 * * \\
(0.019)\end{array}$ & $\begin{array}{l}-0.035^{*} \\
(0.019)\end{array}$ \\
\hline Current UR & $\begin{array}{c}0.853 \\
(0.590)\end{array}$ & $\begin{array}{c}-1.256 * * \\
(0.354)\end{array}$ & $\begin{array}{c}1.537 * * \\
(0.086)\end{array}$ & $\begin{array}{l}-0.218 \\
(0.463)\end{array}$ & $\begin{array}{l}-0.109 \\
(0.212)\end{array}$ & $\begin{array}{c}-0.437 * * \\
(0.149)\end{array}$ \\
\hline (Education - 9) * UR Current & $\begin{array}{l}-0.003 \\
(0.062)\end{array}$ & $\begin{array}{c}0.042 \\
(0.028)\end{array}$ & $\begin{array}{c}-0.069 * * \\
(0.010)\end{array}$ & $\begin{array}{l}0.050^{*} \\
(0.030)\end{array}$ & $\begin{array}{c}0.104 * * \\
(0.027)\end{array}$ & $\begin{array}{c}0.030 \\
(0.021)\end{array}$ \\
\hline $\begin{array}{l}\text { Observations } \\
\text { R-squared }\end{array}$ & $\begin{array}{c}50,590 \\
0.244\end{array}$ & $\begin{array}{c}28,537 \\
0.054\end{array}$ & $\begin{array}{c}86,620 \\
0.158\end{array}$ & $\begin{array}{c}17,697 \\
0.103\end{array}$ & $\begin{array}{c}38,132 \\
0.056\end{array}$ & $\begin{array}{c}19,699 \\
0.061\end{array}$ \\
\hline
\end{tabular}

Note: Standard errors in parentheses are clustered at country-graduation year level. $* * p<0.05, * p<0.1$. Weights in Eurobarometer are applied. Respondents are aged between 25 and 55. The unit of experience is in 10 years. The covariates include years of education, interaction of education with years since graduation and its square term, indicators for gender, graduation cohorts, years since graduation, UR sources, countries, survey years and linear time trends for specific country. 
Table 8. Variation in Gradients and Unemployment Rates

\begin{tabular}{|c|c|c|c|}
\hline \multirow[b]{3}{*}{ Outcomes } & (1) & (2) & (3) \\
\hline & \multicolumn{2}{|c|}{ 90th percentile - 10th percentile } & \multirow[b]{2}{*}{ Ratio $(2) /(1)$} \\
\hline & $\begin{array}{c}\text { Actual Unemployment } \\
\text { rates }\end{array}$ & $\begin{array}{c}\text { Mean Unemployment } \\
\text { rates }\end{array}$ & \\
\hline Income & 0.0228 & 0.0135 & 0.59 \\
\hline Health & 0.0125 & 0.0105 & 0.84 \\
\hline Life dissatisfaction & 0.0079 & 0.0025 & 0.31 \\
\hline Obesity & 0.0133 & 0.0113 & 0.85 \\
\hline Smoke & 0.0061 & 0.0044 & 0.72 \\
\hline Drink & 0.0042 & 0.0032 & 0.77 \\
\hline
\end{tabular}


A1. Unemployment rates data sources

\begin{tabular}{|c|c|c|c|c|c|}
\hline Country & WDI & Layard & OECD & Mitchell & Used in this paper \\
\hline Austria & $1982-2012$ & $1955-1990$ & $1968-2007$ & $1947-2008$ & $1956-2012$ \\
\hline Belgium & $1983-2012$ & $1955-1990$ & $1960-2007$ & 1921-1939, $1948-2003$ & $1954-2012$ \\
\hline Bulgaria & $1993-2012$ & N/A & N/A & $1990-2008$ & $1990-2012$ \\
\hline Croatia & 1991, $1996-2012$ & N/A & N/A & $1981-2007$ & $1981-2012$ \\
\hline Cyprus & $1999-2012$ & N/A & N/A & $1967-2005$ & $1967-2012$ \\
\hline Czech Republic & 1991, $1993-2012$ & N/A & $1990-2007$ & $1990-2008$ & 1990-2012 \\
\hline Denmark & $1983-2012$ & $1955-1990$ & $\begin{array}{c}1960,1965,1967 \\
1969-2007\end{array}$ & $1910-1997,2001-2008$ & 1953-2012 \\
\hline Estonia & $1989-2012$ & N/A & N/A & $1990-1994,1998-2008$ & 1989-2012 \\
\hline Finland & $1980-2012$ & $1955-1990$ & $1960-2007$ & $1958-2008$ & 1956-2012 \\
\hline France & $1980-2012$ & $1955-1990$ & $1960-2007$ & $1900-1913,1970-2008$ & $1955-2012$ \\
\hline Germany & $1991-2012$ & $1955-1990$ & $1960-2007$ & $1900-1938,1948-2008$ & $1955-2012$ \\
\hline Greece & $1981-2012$ & N/A & 1961, $1977-2007$ & $1974-1993,1999-2007$ & $1951-2012$ \\
\hline Hungary & $1992-2012$ & N/A & $1992-2007$ & $1990-1999,2003-2008$ & $1990-2012$ \\
\hline Ireland & $1983-2012$ & $1955-1990$ & $1960-2007$ & $1939-2008$ & $1956-2012$ \\
\hline Italy & $1980-2012$ & $1955-1990$ & $1960-2007$ & $1947-2008$ & $1951-2012$ \\
\hline Latvia & $1996-2012$ & N/A & N/A & $1992-2007$ & $1992-2012$ \\
\hline Lithuania & $1994-2012$ & N/A & N/A & $1991-2008$ & 1991-2012 \\
\hline Luxembourg & $1983-2012$ & N/A & $1974-2007$ & $1975-2008$ & 1953-2012 \\
\hline Macedonia & $1997-2012$ & N/A & N/A & $1982-2000$ & $1982-2012$ \\
\hline Malta & $2000-2012$ & N/A & N/A & $1983-2007$ & 1983-2012 \\
\hline Netherlands & $\begin{array}{c}1981,1983,1985 \\
1987-2012\end{array}$ & $1955-1990$ & $1975-2007$ & $1911-1939,1948-2008$ & $1955-2012$ \\
\hline Poland & $1992-2012$ & N/A & $1990-2007$ & $1927-1938,1990-2008$ & 1990-2012 \\
\hline Portugal & $1980-2012$ & N/A & $1960,1974-2007$ & 1992,1993 & 1960, 1974-2012 \\
\hline Romania & $1994-2012$ & N/A & N/A & $1991-2008$ & 1991-2012 \\
\hline Slovakia & $1993-2012$ & N/A & $1994-2007$ & $1991-2008$ & 1991-2012 \\
\hline Slovenia & 1991, 1993 - 2012 & N/A & N/A & $1986-2006$ & 1986-2012 \\
\hline Spain & $1980-2012$ & $1955-1990$ & $1960-2007$ & $1968-2008$ & $1955-2012$ \\
\hline Sweden & $1980-2012$ & $1955-1990$ & $1963-2007$ & $1925-2008$ & 1952-2012 \\
\hline Switzerland & $1990-2012$ & $1955-1990$ & $1960-2007$ & $1926-1950,1974-2008$ & $1948,1955-2012$ \\
\hline Turkey & 1985, $1987-2012$ & N/A & $1960-2007$ & N/A & 1960 \\
\hline United Kingdom & $1984-2012$ & $1955-1990$ & $1960-2007$ & $1900-2008$ & 1956 \\
\hline
\end{tabular}


A2. Summary statistics, by country

\begin{tabular}{|c|c|c|c|c|c|c|c|c|c|c|c|c|}
\hline \multirow{2}{*}{ Country } & \multicolumn{2}{|c|}{$\begin{array}{c}\text { Household income } \\
\text { sample }\end{array}$} & \multicolumn{2}{|c|}{ Health sample } & \multicolumn{2}{|c|}{$\begin{array}{c}\text { Life Dissatisfaction } \\
\text { sample } \\
\end{array}$} & \multicolumn{2}{|c|}{ Obesity sample } & \multicolumn{2}{|c|}{ Smoke sample } & \multicolumn{2}{|c|}{ Drink sample } \\
\hline & Mean & $\begin{array}{c}\text { Years of } \\
\text { schooling }\end{array}$ & Mean & $\begin{array}{c}\text { Years of } \\
\text { schooling }\end{array}$ & Mean & $\begin{array}{c}\text { Years of } \\
\text { schooling }\end{array}$ & Mean & $\begin{array}{c}\text { Years of } \\
\text { schooling }\end{array}$ & Mean & $\begin{array}{c}\text { Years of } \\
\text { schooling }\end{array}$ & Mean & $\begin{array}{c}\text { Years of } \\
\text { schooling }\end{array}$ \\
\hline \multicolumn{13}{|c|}{ Panel A: Unrestricted sample } \\
\hline Austria & 2.21 & 11.05 & 0.17 & 11.16 & 0.13 & 11.33 & 0.07 & 11.25 & 0.41 & 11.17 & 0.15 & 11.13 \\
\hline Belgium & 2.24 & 11.86 & 0.18 & 12.33 & 0.12 & 12.98 & 0.13 & 12.20 & 0.34 & 12.50 & 0.08 & 12.67 \\
\hline Bulgaria & & & 0.30 & 12.49 & 0.62 & 12.95 & 0.14 & 12.86 & 0.48 & 12.83 & 0.08 & 12.65 \\
\hline Croatia & & & 0.25 & 12.06 & 0.31 & 11.99 & 0.11 & 12.14 & 0.40 & 11.97 & 0.06 & 11.97 \\
\hline Cyprus & & & 0.21 & 11.37 & 0.28 & 11.50 & 0.17 & 12.49 & 0.41 & 11.16 & 0.05 & 10.90 \\
\hline \multicolumn{13}{|l|}{ Czech } \\
\hline Republic & & & 0.21 & 11.95 & 0.21 & 12.01 & 0.08 & 12.04 & 0.34 & 11.96 & 0.05 & 11.94 \\
\hline Denmark & 1.85 & 15.30 & 0.16 & 15.91 & 0.03 & 16.87 & 0.13 & 15.88 & 0.34 & 16.12 & 0.06 & 16.57 \\
\hline Estonia & & & 0.38 & 12.53 & 0.32 & 12.80 & 0.11 & 12.47 & 0.37 & 12.80 & 0.04 & 12.84 \\
\hline Finland & 2.08 & 13.78 & 0.23 & 14.19 & 0.05 & 15.39 & 0.16 & 14.15 & 0.33 & 14.82 & 0.04 & 15.29 \\
\hline France & 2.49 & 11.92 & 0.22 & 12.33 & 0.17 & 12.82 & 0.09 & 12.34 & 0.41 & 12.66 & 0.05 & 12.84 \\
\hline Germany & 2.31 & 11.33 & 0.24 & 11.36 & 0.20 & 11.84 & 0.10 & 11.62 & 0.40 & 11.40 & 0.11 & 11.35 \\
\hline Greece & 2.14 & 10.67 & 0.10 & 11.42 & 0.50 & 11.94 & 0.15 & 11.26 & 0.54 & 11.58 & 0.08 & 11.59 \\
\hline Hungary & & & 0.40 & 10.60 & 0.53 & 10.94 & 0.16 & 10.68 & 0.45 & 10.81 & 0.08 & 10.73 \\
\hline Ireland & 2.25 & 10.67 & 0.09 & 11.11 & 0.12 & 11.65 & 0.12 & 11.12 & 0.35 & 11.26 & 0.08 & 11.37 \\
\hline Italy & 2.42 & 11.56 & 0.21 & 11.49 & 0.28 & 11.85 & 0.06 & 11.62 & 0.33 & 11.58 & 0.09 & 11.43 \\
\hline Latvia & & & 0.51 & 11.87 & 0.42 & 12.17 & 0.16 & 11.90 & 0.40 & 11.87 & 0.03 & 11.89 \\
\hline Lithuania & & & 0.48 & 12.46 & 0.45 & 12.58 & 0.16 & 12.42 & 0.39 & 12.73 & 0.05 & 12.72 \\
\hline Luxembourg & 2.33 & 11.53 & 0.18 & 11.76 & 0.07 & 12.85 & 0.12 & 11.63 & 0.32 & 12.11 & 0.05 & 12.08 \\
\hline Macedonia & & & & & 0.38 & 11.10 & & & 0.43 & 10.75 & & 10.75 \\
\hline Malta & & & 0.17 & 9.98 & 0.21 & 10.18 & 0.24 & 10.10 & 0.29 & 10.11 & 0.03 & 10.12 \\
\hline Netherlands & 2.37 & 12.46 & 0.17 & 13.25 & 0.06 & 14.04 & 0.13 & 12.89 & 0.33 & 13.62 & 0.07 & 14.13 \\
\hline Poland & & & 0.32 & 12.45 & 0.25 & 12.81 & 0.13 & 12.61 & 0.41 & 12.59 & 0.02 & 12.59 \\
\hline Portugal & 2.46 & 7.74 & 0.33 & 8.15 & 0.51 & 8.44 & 0.12 & 8.01 & 0.32 & 8.43 & 0.10 & 8.58 \\
\hline Romania & & & 0.29 & 12.17 & 0.53 & 12.30 & 0.11 & 12.27 & 0.36 & 12.20 & 0.13 & 12.14 \\
\hline \multicolumn{13}{|l|}{ Slovak } \\
\hline Republic & & & 0.26 & 12.04 & 0.33 & 12.17 & 0.11 & 12.25 & 0.30 & 12.12 & 0.06 & 12.09 \\
\hline Slovenia & & & 0.18 & 12.48 & 0.13 & 12.73 & 0.09 & 12.56 & 0.31 & 12.67 & 0.05 & 12.69 \\
\hline Spain & 2.14 & 10.33 & 0.14 & 10.86 & 0.22 & 11.00 & 0.10 & 10.90 & 0.45 & 10.95 & 0.13 & 10.84 \\
\hline Sweden & 2.28 & 14.14 & 0.21 & 14.99 & 0.04 & 16.11 & 0.10 & 15.23 & 0.27 & 15.45 & 0.01 & 15.54 \\
\hline Turkey & & & 0.21 & 7.71 & 0.33 & 7.89 & 0.12 & 7.97 & 0.42 & 7.99 & & 7.99 \\
\hline \multicolumn{13}{|l|}{ United } \\
\hline Kingdom & 2.23 & 10.18 & 0.22 & 10.60 & 0.11 & 11.24 & 0.18 & 10.57 & 0.38 & 10.96 & 0.11 & 11.19 \\
\hline \multicolumn{13}{|c|}{ Panel B: Restricted sample } \\
\hline Austria & 2.21 & 11.05 & 0.17 & 11.16 & 0.13 & 11.33 & 0.07 & 11.25 & 0.41 & 11.16 & 0.15 & 11.13 \\
\hline Belgium & 2.24 & 11.86 & 0.18 & 12.33 & 0.12 & 12.97 & 0.13 & 12.20 & 0.34 & 12.50 & 0.08 & 12.67 \\
\hline Bulgaria & & & 0.16 & 13.95 & 0.54 & 14.22 & 0.06 & 14.75 & 0.50 & 13.91 & 0.06 & 13.73 \\
\hline Croatia & & & 0.16 & 12.67 & 0.27 & 12.46 & 0.07 & 12.77 & 0.41 & 12.54 & 0.05 & 12.54 \\
\hline Cyprus & & & 0.19 & 11.71 & 0.28 & 11.70 & 0.16 & 12.90 & 0.41 & 11.35 & 0.05 & 11.07 \\
\hline \multicolumn{13}{|l|}{ Czech } \\
\hline Republic & & & 0.09 & 12.47 & 0.18 & 12.50 & 0.03 & 12.63 & 0.31 & 12.37 & 0.05 & 12.31 \\
\hline Denmark & 1.85 & 15.30 & 0.16 & 15.91 & 0.03 & 16.85 & 0.13 & 15.88 & 0.34 & 16.10 & 0.06 & 16.57 \\
\hline Estonia & & & 0.23 & 13.70 & 0.24 & 13.87 & 0.07 & 13.64 & 0.34 & 13.81 & 0.03 & 14.00 \\
\hline Finland & 2.08 & 13.78 & 0.23 & 14.19 & 0.05 & 15.35 & 0.16 & 14.15 & 0.33 & 14.81 & 0.04 & 15.29 \\
\hline France & 2.49 & 11.92 & 0.22 & 12.33 & 0.17 & 12.81 & 0.09 & 12.34 & 0.41 & 12.66 & 0.05 & 12.84 \\
\hline Germany & 2.31 & 11.33 & 0.24 & 11.36 & 0.20 & 11.83 & 0.10 & 11.62 & 0.39 & 11.40 & 0.11 & 11.35 \\
\hline Greece & 2.08 & 12.12 & 0.07 & 12.45 & 0.50 & 12.48 & 0.13 & 12.15 & 0.55 & 12.33 & 0.09 & 12.22 \\
\hline Hungary & & & 0.19 & 11.61 & 0.47 & 11.73 & 0.09 & 12.02 & 0.43 & 11.58 & 0.03 & 11.51 \\
\hline Ireland & 2.25 & 10.67 & 0.09 & 11.11 & 0.12 & 11.65 & 0.12 & 11.12 & 0.35 & 11.26 & 0.08 & 11.37 \\
\hline
\end{tabular}




\begin{tabular}{lcccccccccccc} 
Italy & 2.42 & 11.56 & 0.21 & 11.49 & 0.28 & 11.84 & 0.06 & 11.62 & 0.33 & 11.58 & 0.09 & 11.43 \\
Latvia & & & 0.31 & 12.91 & 0.33 & 13.17 & 0.05 & 13.19 & 0.40 & 12.76 & 0.03 & 12.75 \\
Lithuania & & & 0.33 & 13.34 & 0.33 & 13.41 & 0.09 & 13.02 & 0.37 & 13.75 & 0.03 & 13.42 \\
Luxembourg & 2.30 & 12.26 & 0.15 & 12.55 & 0.06 & 13.28 & 0.09 & 12.45 & 0.32 & 12.70 & 0.05 & 12.62 \\
Macedonia & & & & & 0.36 & 11.61 & & & 0.39 & 11.47 & & 11.47 \\
Malta & & & 0.09 & 11.46 & 0.19 & 11.15 & 0.17 & 12.02 & 0.31 & 11.11 & 0.02 & 10.97 \\
Netherlands & 2.37 & \multirow{2}{*}{12.46} & 0.17 & 13.25 & 0.06 & 14.02 & 0.13 & 12.89 & 0.33 & 13.62 & 0.07 & 14.13 \\
Poland & & & 0.20 & 13.72 & 0.17 & 13.82 & 0.06 & 13.97 & 0.36 & 13.82 & 0.03 & 13.66 \\
Portugal & 2.33 & 9.41 & 0.24 & 9.58 & 0.49 & 9.47 & 0.11 & 9.34 & 0.36 & 9.66 & 0.08 & 9.68 \\
Romania & & & 0.15 & 13.91 & 0.46 & 13.51 & 0.05 & 14.16 & 0.40 & 13.43 & 0.11 & 13.68 \\
Slovak & & & & & & & & & & & & \\
Republic & & & 0.13 & 12.63 & 0.26 & 12.74 & 0.05 & 12.50 & 0.29 & 12.77 & 0.05 & 12.83 \\
Slovenia & & & 0.08 & 13.73 & 0.11 & 13.77 & 0.05 & 14.00 & 0.32 & 13.80 & 0.02 & 13.89 \\
Spain & 2.14 & 10.41 & 0.14 & 10.86 & 0.22 & 10.99 & 0.10 & 10.90 & 0.45 & 10.95 & 0.13 & 10.84 \\
Sweden & 2.28 & 14.14 & 0.21 & 14.99 & 0.04 & 16.10 & 0.10 & 15.23 & 0.27 & 15.45 & 0.01 & 15.54 \\
Turkey & & & 0.21 & 7.71 & 0.33 & 7.89 & 0.12 & 7.97 & 0.42 & 7.99 & & 7.99 \\
United & & & & & & & & & & & \\
Kingdom & 2.23 & 10.18 & 0.22 & 10.60 & 0.11 & 11.23 & 0.18 & 10.57 & 0.38 & 10.95 & 0.11 & 11.19 \\
\hline \hline
\end{tabular}




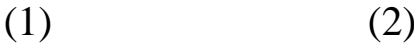

2)

(3)

Income Quartile

(1:highest - 4:lowest)
General Poor Life dissatisfaction

(Yes = 1)
$(0.072)$

$-0.047 * *$

$(0.010)$

$0.004 * *$

(0.002)

$-0.009 * *$

$(0.002)$

$0.001 * *$

(0.001)

$0.007 * *$

(0.003)

$-0.091 * *$

(0.003)

0.923 **

(0.017)

50,590

0.259
(4)

(5)

(6)

Smoker Daily drinker

$($ Yes = 1) $\quad($ Yes = 1)

\begin{tabular}{|c|c|c|c|c|c|c|}
\hline Observations & 50,590 & 28,440 & 87,450 & 17,697 & 48,367 & 19,656 \\
\hline R-squared & 0.259 & 0.063 & 0.169 & 0.038 & 0.073 & 0.065 \\
\hline
\end{tabular}

Note: All standard errors are clustered at country-graduation year level. $* * \mathrm{p}<0.05, * \mathrm{p}<0.1$. Weights in Eurobarometer are applied. Respondents are aged between 25 and 55. The unit of experience is in 10 years. The covariates include indicators for gender, marital status, graduation cohorts, years since graduation, UR sources, countries, survey years, country interacting with survey years and linear time trends for specific country. 
A4: Marginal Effects of Unemployment rates when graduating and Education on Outcomes

(1) (2) (3)

Dependent variables

Lower household General Poor income $($ Yes $=1)$ Health $($ Yes = 1)
Life

\section{(4)}

Obesity

dissatisfaction

$($ Yes $=1)$

(Yes =1)
(5)

(6)

Smoker

$($ Yes $=1)$

Daily drinker

(Yes = 1)

\begin{tabular}{lcccccc}
\hline & & & & & & \\
UR when graduating & $0.554 * * *$ & 0.105 & 0.0399 & 0.791 & $0.397 * * *$ & 0.121 \\
(3 years average) & $(0.203)$ & $(0.150)$ & $(0.0642)$ & $(1.055)$ & $(0.125)$ & $(0.0816)$ \\
(Education - 9)* UR & $-0.0536^{*}$ & $-0.0433 * *$ & $-0.0218 * *$ & $-0.267 *$ & $-0.0414 * *$ & -0.0173 \\
& $(0.0303)$ & $(0.0196)$ & $(0.00873)$ & $(0.138)$ & $(0.0196)$ & $(0.0126)$
\end{tabular}

Observations

50,590

28,440

87,450

17,697

48,367

19,639

Note: All columns are estimated in logistic model. Marginal effects at mean are reported. Standard errors in parentheses are clustered at countrygraduation year level. Weights in Eurobarometer are applied. Higher household income is defined as the household income belongs to the first two quartiles. Respondents are aged between 25 and 55. The unit of experience is in 10 years. The covariates include years of education, interaction of education with years since graduation and its square term, indicators for gender, marital status, graduation cohorts, years since graduation, UR sources, countries, survey years, country interacting with survey years and linear time trends for specific country. 


\begin{tabular}{|c|c|c|c|c|c|c|}
\hline & $\begin{array}{c}\text { (1) } \\
\text { Income Quartile } \\
\text { (1:highest - 4:lowest) }\end{array}$ & $\begin{array}{c}(2) \\
\text { General Poor } \\
\text { Health }(\text { Yes }=1) \\
\end{array}$ & $\begin{array}{c}\text { (3) } \\
\text { Life dissatisfaction } \\
(\text { Yes }=1)\end{array}$ & $\begin{array}{c}(4) \\
\text { Obesity } \\
(\text { Yes }=1) \\
\end{array}$ & $\begin{array}{c}(5) \\
\text { Smoker } \\
(\text { Yes = 1) } \\
\end{array}$ & $\begin{array}{c}(6) \\
\text { Daily drinker } \\
(\text { Yes }=1) \\
\end{array}$ \\
\hline UR when graduating ( 3 years & $2.851 * *$ & 0.267 & $0.421 * *$ & 0.006 & $0.491 * *$ & 0.037 \\
\hline average) & $(0.574)$ & $(0.184)$ & $(0.109)$ & $(0.173)$ & $(0.192)$ & $(0.170)$ \\
\hline \multirow[t]{2}{*}{$($ Education - 9) $*$ UR } & $-0.657 * *$ & $-0.096 * *$ & $-0.129 * *$ & $-0.069 * *$ & $-0.164 * *$ & $-0.059 * *$ \\
\hline & $(0.072)$ & $(0.024)$ & $(0.014)$ & $(0.025)$ & $(0.026)$ & $(0.024)$ \\
\hline \multirow[t]{2}{*}{$($ Age -25$) * \mathrm{UR}$} & $-0.214 * *$ & -0.025 & $-0.030 * *$ & 0.008 & -0.007 & 0.018 \\
\hline & $(0.048)$ & $(0.016)$ & $(0.008)$ & $(0.014)$ & $(0.016)$ & $(0.014)$ \\
\hline$($ Education -9$) *($ Age -25$) *$ & $0.056 * *$ & $0.006 * *$ & $0.007 * *$ & 0.001 & $0.009 * *$ & 0.001 \\
\hline UR & $(0.004)$ & $(0.001)$ & $(0.001)$ & $(0.001)$ & $(0.001)$ & $(0.001)$ \\
\hline \multirow[t]{2}{*}{ Years of schooling } & 0.011 & $0.007 * *$ & $0.007 * *$ & $0.009 * *$ & 0.003 & -0.002 \\
\hline & $(0.009)$ & $(0.004)$ & $(0.002)$ & $(0.004)$ & $(0.004)$ & $(0.003)$ \\
\hline \multirow[t]{2}{*}{ Education $*$ Experience } & $-0.068 * *$ & -0.001 & $-0.011 * *$ & -0.003 & $-0.018 * *$ & 0.004 \\
\hline & $(0.008)$ & $(0.004)$ & $(0.002)$ & $(0.004)$ & $(0.004)$ & $(0.003)$ \\
\hline \multirow[t]{2}{*}{ Education $*$ Experience $^{2}$} & $0.010^{* *}$ & -0.001 & $0.001 * *$ & -0.001 & $0.003^{* *}$ & -0.001 \\
\hline & $(0.002)$ & $(0.001)$ & $(0.001)$ & $(0.001)$ & $(0.001)$ & $(0.001)$ \\
\hline Observations & 50,590 & 28,440 & 87,450 & 17,734 & 48,367 & 19,656 \\
\hline R-squared & 0.266 & 0.063 & 0.170 & 0.038 & 0.074 & 0.065 \\
\hline
\end{tabular}

Note: All standard errors are clustered in country-graduation year level. $* * \mathrm{p}<0.05, * \mathrm{p}<0.1$. Weights in Eurobarometer are applied.

Respondents are aged between 25 and 55. The unit of experience is in 10 years. The covariates include indicators for gender, marital status, graduation cohorts, years since graduation, UR sources, countries, survey years, country interacting with survey years and linear time trends for snecific countrv. 
A6: Education choice and Unemployment Rate when Graduating

\begin{tabular}{lcc}
\hline \hline & $(1)$ & $(2)$ \\
VARIABLES & Years of education & Married (Yes $=1)$ \\
\hline & & \\
UR when graduating & -0.508 & $0.268^{* * *}$ \\
Years of education & $(0.581)$ & $(0.0722)$ \\
UR*(Education - 9) & & $0.00416^{* * *}$ \\
& & $(0.000705)$ \\
& & 0.0114 \\
Observations & & $(0.00782)$ \\
R-squared & 295,295 & 294,951 \\
\hline \hline
\end{tabular}

Note: Standard errors in parentheses are clustered at country-graduation year level, and those in brackets are clustered at country level. $* * \mathrm{p}<0.05, * \mathrm{p}<0.1$. Weights in Eurobarometers are applied. Samples are combined together. Respondents are aged between 25 and 55. The covariates include indicators for gender, graduation cohorts, years since graduation, UR sources, countries, survey years, sample sources, country interacting with survey years and linear time trends for specific country. 


\begin{tabular}{|c|c|c|c|c|c|c|}
\hline Dependent variables & $\begin{array}{c}(1) \\
\text { Income Quartile } \\
\text { (1:highest - 4:lowest) }\end{array}$ & $\begin{array}{c}(2) \\
\text { General Poor } \\
\text { Health }(\text { Yes = 1) }\end{array}$ & $\begin{array}{c}\text { (3) } \\
\text { Life } \\
\text { dissatisfaction } \\
(\text { Yes }=1) \\
\end{array}$ & Obesity (Yes =1) & $\begin{array}{c}(5) \\
\text { Smoker } \\
(\text { Yes = 1) }\end{array}$ & $\begin{array}{c}(6) \\
\text { Daily drinker } \\
(\text { Yes }=1)\end{array}$ \\
\hline UR when graduating ( 3 & $0.717 * *$ & 0.035 & 0.090 & 0.078 & $0.265 * *$ & $0.198 *$ \\
\hline years average) & $(0.355)$ & $(0.122)$ & $(0.067)$ & $(0.129)$ & $(0.114)$ & $(0.111)$ \\
\hline$($ Education -9$) * U R$ & $-0.113 * *$ & $-0.033 * *$ & $-0.044 * *$ & $-0.048 * *$ & $-0.036 * *$ & -0.026 \\
\hline Observations & 50,590 & 28,537 & 87,450 & 17,734 & 48,460 & 19,699 \\
\hline R-squared & 0.105 & 0.057 & 0.159 & 0.038 & 0.060 & 0.062 \\
\hline \multicolumn{7}{|c|}{ Panel B: Unemployment Rate in year of graduation } \\
\hline UR when graduating & $0.806^{* *}$ & 0.045 & $0.121 *$ & 0.028 & $0.409 * *$ & $0.208 *$ \\
\hline Observations & 50,590 & 28,537 & 87,450 & 17,734 & 48,460 & 19,699 \\
\hline R-squared & 0.105 & 0.057 & 0.159 & 0.038 & 0.060 & 0.062 \\
\hline
\end{tabular}


A8: Education, Unemployment Rates by Education and Outcomes in Eurobarometer

\begin{tabular}{|c|c|c|c|c|c|c|}
\hline & $(1)$ & (2) & (3) & (4) & $(5)$ & (6) \\
\hline Dependent variables & $\begin{array}{c}\text { Income Quartile } \\
\text { (1:highest - 4:lowest) }\end{array}$ & $\begin{array}{c}\text { General Poor } \\
\text { Health }(\text { Yes }=1)\end{array}$ & $\begin{array}{l}\text { Life dissatisfaction } \\
(\text { Yes }=1)\end{array}$ & $\begin{array}{l}\text { Obesity } \\
(\text { Yes }=1)\end{array}$ & $\begin{array}{l}\text { Smoker } \\
(\text { Yes = 1) }\end{array}$ & $\begin{array}{l}\text { Daily drinker } \\
\quad(\text { Yes = 1) }\end{array}$ \\
\hline \multicolumn{7}{|c|}{ Panel A: Unemployment rates by education level } \\
\hline UR when graduating, by & 0.299 & 0.074 & $0.159 * *$ & 0.073 & $0.455 * *$ & $0.131 *$ \\
\hline education level & $(0.224)$ & $(0.078)$ & $(0.045)$ & $(0.135)$ & $(0.073)$ & $(0.072)$ \\
\hline \multirow[t]{2}{*}{$($ Education - 9) $*$ UR } & $-0.131 * *$ & -0.025 & $-0.001 * *$ & -0.036 & $-0.055 * *$ & -0.016 \\
\hline & $(0.049)$ & $(0.019)$ & $(0.000)$ & $(0.032)$ & $(0.019)$ & $(0.017)$ \\
\hline Observations & 50,590 & 28,440 & 87,450 & 17,697 & 48,367 & 19,656 \\
\hline R-squared & 0.263 & 0.063 & 0.170 & 0.097 & 0.075 & 0.066 \\
\hline \multicolumn{7}{|c|}{ Panel B: Total Unemployment rates interacting with education level categorical dummies } \\
\hline \multirow[t]{2}{*}{ UR when graduating } & $1.195 * *$ & 0.142 & $0.165^{*}$ & -0.034 & 0.219 & 0.241 \\
\hline & $(0.379)$ & $(0.153)$ & $(0.093)$ & $(0.290)$ & $(0.147)$ & $(0.171)$ \\
\hline \multirow[t]{2}{*}{ UR $*$ (Years of education $9-12$ ) } & -0.256 & -0.149 & $-0.195 * *$ & 0.012 & -0.037 & -0.148 \\
\hline & $(0.300)$ & (0.139) & $(0.093)$ & $(0.251)$ & $(0.138)$ & $(0.172)$ \\
\hline \multirow[t]{2}{*}{ UR * (Years of education 13+) } & $-0.922 *$ & $-0.585 * *$ & $-0.478 * *$ & -0.221 & $-0.312 *$ & -0.270 \\
\hline & $(0.476)$ & $(0.178)$ & $(0.110)$ & $(0.338)$ & $(0.178)$ & $(0.201)$ \\
\hline Observations & 50,590 & 28,440 & 87,450 & 17,697 & 48,367 & 19,656 \\
\hline R-squared & 0.263 & 0.064 & 0.170 & 0.096 & 0.074 & 0.066 \\
\hline
\end{tabular}

